NBER WORKING PAPER SERIES

\title{
INTERNATIONAL CURRENCY EXPOSURES, VALUATION EFFECTS, AND THE GLOBAL FINANCIAL CRISIS
}

\author{
Agustín S. Bénétrix \\ Philip R. Lane \\ Jay C. Shambaugh \\ Working Paper 20820 \\ http://www.nber.org/papers/w20820 \\ NATIONAL BUREAU OF ECONOMIC RESEARCH \\ 1050 Massachusetts Avenue \\ Cambridge, MA 02138 \\ January 2015
}

Prepared for 2014 International Seminar on Macroeconomics, Riga, June 27-28 2014. We are grateful for feedback from our discussants Gian Maria Milesi-Ferretti and Bob McCauley. We thank Jeff Frankel, the participants of the 2014 International Seminar on Macroeconomics conference and seminars at the European Central Bank and Trinity College Dublin for comments. We thank Rogelio Mercado, Caroline Mehigan and Alex Redmond for research assistance. Benetrix thanks the Irish Research Council and Lane thanks the Institute for New Economic Thinking for financial support. The views expressed herein are those of the authors and do not necessarily reflect the views of the National Bureau of Economic Research.

NBER working papers are circulated for discussion and comment purposes. They have not been peerreviewed or been subject to the review by the NBER Board of Directors that accompanies official NBER publications.

(C) 2015 by Agustín S. Bénétrix, Philip R. Lane, and Jay C. Shambaugh. All rights reserved. Short sections of text, not to exceed two paragraphs, may be quoted without explicit permission provided that full credit, including $\odot$ notice, is given to the source. 
International Currency Exposures, Valuation Effects, and the Global Financial Crisis Agustín S. Bénétrix, Philip R. Lane, and Jay C. Shambaugh

NBER Working Paper No. 20820

January 2015

JEL No. F3,F31

\begin{abstract}
$\underline{\text { ABSTRACT }}$
We examine the evolution of international currency exposures, with a particular focus on the 2002-12 period. During the run up to the global financial crisis, there was a widespread shift towards positive net foreign currency positions, such that relatively few countries exhibited the archetypal emerging-market Ishort foreign currency" position on the eve of the global financial crisis. During the crisis, the upheaval in currency markets generated substantial currency-generated valuation effects - much of which were not reversed. There is some evidence that the distribution of valuation effects was stabilizing in the sense of showing a negative covariation pattern with pre-crisis net foreign asset positions.
\end{abstract}

\author{
Agustín S. Bénétrix \\ Department of Economics and IIIS \\ Trinity College \\ Dublin \\ benetria@tcd.ie \\ Philip R. Lane \\ The Sutherland Centre \\ Arts Block \\ Trinity College Dublin \\ Dublin 2 IRELAND \\ plane@tcd.ie
}

\author{
Jay C. Shambaugh \\ George Washington University \\ Elliot School for International Affairs \\ 1957 E Street, N.W. Suite 502 \\ Washington, D.C. 20052 \\ and NBER \\ jshambaugh@gwu.edu
}




\section{Introduction}

International currency exposures vary across countries and over time, due to differences in the scale and composition of international balance sheets. Historically, a long-standing distinction was made between advanced economies that could issue domestic-currency liabilities to foreign investors and emerging economies that could only obtain foreigncurrency loans. For the former group, unanticipated currency depreciation confers a valuation gain by increasing the local-currency value of foreign assets relative to foreign liabilities. For the latter group, currency depreciation induces adverse balance sheet effects. $^{1}$

However, in the wake of the 1990s emerging market crises, the international currency exposures of the latter group has sharply changed. A combination of current account surpluses, the accumulation of foreign-currency official reserve assets, a shift from debtbased to equity-based liability funding and success in building local-currency debt markets resulted in improved net foreign currency positions in the run up the global financial crisis (Lane and Shambaugh 2010a). Accordingly, these countries were better positioned to absorb this global shock, since currency depreciation could be deployed to counter the external shock without worrying about adverse balance sheet effects.

At the same time, there was rapid growth in the external balance sheets of advanced economies during the pre-crisis period (Lane and Milesi-Ferretti 2007a, 2008, Lane 2013a). With foreign currencies forming a higher proportion of foreign assets than foreign liabilities, the net foreign currency exposures of advanced economies climbed, such that the valuation impact of a given shift in exchange rates was larger than in earlier periods.

In view of these structural changes and the scale of the exchange rate changes during the global financial crisis in 2008-2009, it is important to quantify the contribution of the valuation channel of exchange rate adjustment. This is the focus of this paper. Our primary aim is to calculate the valuation impact of currency movements during 2008-2009.

\footnotetext{
${ }^{1}$ See, amongst many others, Calvo and Reinhart (2002), Eichengreen et al (2003), Goldstein and Turner (2004) and Eichengreen and Hausmann (2005).
} 
To this end, we extend previous work to estimate international currency exposures for 1990-2012 and use these data to calculate the valuation impact of shifts in financiallyweighted exchange rate indices.

In addition, our secondary aim is to ask whether these valuation effects were stabilising from a global perspective. In particular, we examine whether currency-based valuation effects helped to correct excessive external imbalances and/or provided a buffer to domestic macroeconomic and financial shocks.

This paper builds on the earlier analysis provided by Lane and Shambaugh (2010a, 2010b). However, the original dataset only extended to 2004, such that post-2004 developments were not covered. In earlier work, the balance sheet implications of exchange rate movements were empirically studied by, amongst many others, Tille (2003), Eichengreen et al (2003), Goldstein and Turner (2004), Eichengreen and Hausmann (2005), Lane and Milesi-Ferretti (2005, 2007b) and Gourinchas and Rey (2007). A comprehensive review of the role played by the valuation mechanism in international macroeconomics is provided by Gourinchas and Rey (2014).

Some recent contributions have inspected various dimensions of the international valuation mechanism in relation to the cross-border distribution of the costs of the 2008-2009 global financial crisis (Milesi-Ferretti 2009, Acharya and Schnabl 2010, European Commission 2010, Gourinchas et al 2012, Lane 2012, Lane 2013a, Lane and Milesi-Ferretti 2014). In addition, Lane and Milesi-Ferretti (2007b), Milesi-Ferretti et al (2010) and Kubelec and $\mathrm{Sa}$ (2012) developed estimates of the geographic compostion of international financial crises on the eve of the crisis. However, none of these studies isolated the currency dimension that is the focus of this paper.

The rest of the paper is structured as follows. We describe the analytical framework and the methods behind the construction of the dataset in Section 2. Section 3 describes the evolution of international currency exposures and highlights key stylized facts. The econometric analysis is reported in Section 4. Finally, Section 5 concludes. 


\section{International Currency Exposures and the Valua- tion Mechanism}

In working out the international balance sheet impact of financial shocks, the valuation channel is a primary transmission mechanism. At a general level, the role of the valuation channel in the dynamics of the external position can be expressed using the following accounting framework. The change in the net foreign asset position between periods $t-1$ and $t$ can be written as

$$
N I I P_{i t}-N I I P_{i t-1}=C A_{i t}+S F A_{i t}
$$

where $C A_{i t}$ is the current account balance and $S F A_{t}$ is the stock-flow adjustment term. In turn, the stock-flow adjustment term can be written as

$$
S F A_{t}=V A L_{i t}+N E T O T H_{i t}
$$

where $V A L_{i t}$ is the net capital gain on the existing holdings of foreign assets and liabilities and $N E T O T H_{i t}$ captures other non-flow changes to the net international investment position (for example, due to changes in reporting methods and data revisions). At a conceptual level, the $V A L_{i t}$ term is a key variable, since it captures the net balance sheet impact of changes in asset prices and market prices (see Gourinchas and Rey 2014 for a survey of the related literature). Accordingly, it should convey a considerable amount of information in relation to the international transmission of financial shocks. Regrettably, just the overall $S F A_{i t}$ term is reported for most countries, so that it is not directly possible to infer the values for $V A L_{i t}$ and $N E T O T H_{i t}{ }^{2}$

\footnotetext{
${ }^{2}$ The United States is an important exception in providing the decomposition. See Curcuru et al (2008, 2013), Lane and Milesi-Ferretti (2009) and Gohrband and Howell (2014) on the important role of the $O T H_{t}$ term in explaining the evolution of the US net international investment position.
} 
A standard approach is to split the valuation term between two components

$$
V A L_{i t}=V A L X R_{i t}+V A L M V_{i t}
$$

where $V A L X R_{i t}$ and $V A L M V_{i t}$ respectively capture the net valuation effects of shifts in currency values and asset prices. Of course, as is extensively discussed by Lane and Shambaugh (2010a), exchange rates and asset prices can be quite correlated, so that the overall impact of a given exchange rate movement depends on the associated response of domestic and foreign asset prices.

Exchange rate movements represent an important potential source of cross-border valuation effects, since the currency composition of foreign assets and foreign liabilites can often be highly asymmetric. Indeed, the rapid expansion in the scale of cross-border investment positions means that currency movements can have potentially large balance sheet effects, in addition to operating through the traditional trade balance channel (Lane and Milesi-Ferretti 2005).

While the official balance of payments and international investment position data do not record the currency composition of foreign assets and foreign liabilities, Lane and Shambaugh (2010a) show how it is possible to construct estimates of international currency exposures by drawing on a range of datasets and inferential techniques. This involves a two-step process in which the currency composition within individual investment categories are first calculated, before obtaining aggregate exposures by weighting across categories in line with their shares in the international balance sheet.

For equity-type assets, this approach asserts that currency exposures track geographic exposures. ${ }^{3}$ Information on the geographical patterns in foreign assets can be obtained from the IMF's Coordinated Portfolio Investment Survey (CPIS) for portfolio equity assets, with the IMF's Coordinated Direct Investment Survey (CDIS) and the UNCTAD bilateral FDI database provide similar data for FDI holdings.

\footnotetext{
${ }^{3}$ The process by which estimates of the currency composition of foreign liabilities are constructed is essentially symmetric.
} 
The CPIS dataset also provides the geographical pattern in portfolio debt assets, while the BIS locational banking statistics contain information on the geography of bank-type debt assets. ${ }^{4}$ Since debt issuers in a given country can issue in foreign currencies as well as in domestic currency, the geographical data is combined with country-level and BIS data on the currency denomination of debt instruments to work out the currency exposures in cross-border debt positions.

Finally, estimates of the currency composition of official reserve assets are calculated through a combination of national data sources, COFER data and the implementation of the empirical model developed by Eichengreen and Mathieson (2000).

In the second step, the currency composition data for each category within foreign assets and foreign liabilities are combined to create aggregate weights, using the External Wealth of Nations dataset on the composition of international balance sheets (Lane and Milesi-Ferretti 2007).

The currency weights are given by the formulae

$$
\omega_{i j t}^{A}=\sum_{k=1}^{k=N} \lambda_{i t}^{A k} * \omega_{i j t}^{A k} ; \quad \omega_{i j t}^{L}=\sum_{k=1}^{k=N} \lambda_{i t}^{L k} * \omega_{i j t}^{L k}
$$

where $\omega_{i j t}^{A}, \omega_{i j t}^{L}$ are the weights for currency $j$ in period $t$ in country $i$ 's foreign assets and foreign liabilities, $\lambda_{i t}^{A k}, \lambda_{i t}^{L k}$ are the relative importance of category $k$ (portfolio equity, FDI, debt, reserves) in country $i$ 's assets and liabilities in period $t$ and $\omega_{i j t}^{A k}, \omega_{i j t}^{L k}$ are the weights for currency $j$ in period $t$ in category $k$ for country $i$ 's assets and liabilities respectively. Accordingly, the aggregate weights are a function of the weights for currency $j$ in period $t$ for a particular $k$ asset-class of country $i$ 's assets or liabilities, and the weights across the $k$ asset classes (represented by $\lambda_{i t}^{k}$ ).

It is possible to define aggregate net financial weights

$$
\omega_{i j t}^{F}=\omega_{i j t}^{A} s_{i t}^{A}-\omega_{i j t}^{L} s_{i t}^{L}
$$

\footnotetext{
${ }^{4}$ The BIS Statistics Department facilitated access to the underlying geographical and currency patterns in the locational banking data.
} 
where $s_{i t}^{A}=A_{i t} /\left(A_{i t}+L_{i t}\right)$ and $s_{i t}^{L}=L_{i t} /\left(A_{i t}+L_{i t}\right)$ are the shares of foreign assets and foreign liabilities in total cross-border holdings. These weights indicate the direction of the valuation impact of a movement in currency $j$. If the net foreign asset position is zero, this reduces to simply subtracting the liability weights from the asset weights.

In turn, the quantitative exposure of country $i$ to a shift in the bilateral exchange rate between $i$ and $j$ can be simply written as

$$
N E T F X_{i j t}^{B I L A T}=\omega_{i j t}^{F} * I F I_{i t}
$$

where $I F I_{i t}$ is equal to assets plus liabilities as a percentage of GDP, or the total size of the external balance sheet scaled by GDP, such that the valuation impact can be written as

$$
V A L X R_{i j t}^{B I L A T}=N E T F X_{i j t}^{B I L A T} * \% \Delta E_{i j t}
$$

where $\% \Delta E_{i j t}$ is the percentage change in the bilateral exchange rate in period $t$. By way of illustration, if in a given year, 20 percent of Mexico's assets are in U.S. dollars and 30 percent of its liabilities are in dollars, and Mexico has a balanced NFA position (that is, assets equal liabilities), then the $\omega_{i j t}^{F}=-.05=(.2 * .5-.3 * .5)$. If assets plus liabilities are equivalent to 200 percent of Mexico's GDP, then $N E T F X_{i j t}^{B I L A T}$ is -10 percent. Thus a 10 percent depreciation of the peso against the dollar (holding fixed all other bilateral exchange rates) would generate a 1 percent of GDP wealth loss.

In terms of aggregation across all bilateral currency pairs, it is helpful to define assetand liability-weighted currency indices

$$
\begin{aligned}
I_{t}^{A} & =I_{t-1}^{A}\left(1+\sum \omega_{i j t-1}^{A} * \% \Delta E_{i j t}\right) \\
I_{t}^{L} & =I_{t-1}^{L}\left(1+\sum \omega_{i j t-1}^{L} * \% \Delta E_{i j t}\right)
\end{aligned}
$$


In turn, the aggregate net financial index can be written as

$$
I_{t}^{F}=I_{t-1}^{F}\left(1+\sum \omega_{i j t-1}^{F} * \% \Delta E_{i j t}\right)
$$

and the aggregate impact of currency-based valuation effects can be equivalently written as

$$
V A L X R_{i t}=\% \Delta I_{i t}^{F} * I F I_{i t-1}
$$

or

$$
V A L X R_{i t}=\sum V A L X R_{i j t}^{B I L A T}=\sum N E T F X_{i j t}^{B I L A T} * \% \Delta E_{i j t}
$$

In addition, it is also useful to develop a measure of aggregate foreign-currency exposure, which is relevant in capturing the sensitivity of a country's external balance sheet to a uniform movement of its domestic currency against all foreign currencies. We define aggregate foreign currency exposure at the end of period $t$ by

$$
F X A G G_{i t}=\omega_{i t}^{A} s_{i t}^{A}-\omega_{i t}^{L} s_{i t}^{L}
$$

where $\omega_{i t}^{A}$ is the share of foreign assets denominated in foreign currencies, $s_{i t}^{A}$ is the share of foreign assets in the sum of foreign assets and foreign liabilities and $\omega_{i t}^{L}, s_{i t}^{L}$ are defined analogously. By construction, the $F X A G G$ index lies in the range $(-1,1)$, where a value of -1 corresponds to a country that has zero foreign-currency foreign assets and only foreign-currency foreign liabilities (a caricature of the traditional profile of a nonadvanced economy), whereas +1 corresponds to a country that has only foreign-currency foreign assets and only domestic-currency foreign liabilities (a caricature of the traditional profile of an advanced economy with a reserve-status currency).

Aggregate foreign currency exposure captures the sensitivity of a country's portfolio to a uniform currency movement by which the home currency moves proportionally against all foreign currencies. In turn, the quantitative exposure to a uniform shift in the value of the domestic currency against all foreign currencies is given by 


$$
N E T F X_{i t}=F X A G G_{i t} * I F I_{i t}
$$

such that valuation impact of a hypothetical uniform exchange rate movement against all partner currencies can be calculated by

$$
V A L X R_{i t}^{U}=N E T F X_{i t} * \% \Delta E_{i t}^{U}
$$

where $\% \Delta E_{i t}^{U}$ denotes the scale of the uniform exchange rate movement. Accordingly, $\left(N E T F X, V A L X R^{U}\right)$ are helpful concepts in conducting scenario analysis or simulating two-country models.

Two concerns are worthy of mention. The first is the use of derivatives. International data provides little in the way of detailed derivatives positions at the country level. Lane and Shambaugh (2010a) discuss the issue at length. To the extent that derivatives move exposure within a country, the issue is irrelevant to our country balance sheets. It is only the sale of exposures across the border that matter to our estimates. To the extent that it is typically advanced economies (who tend to be long foreign currency) that engage in the use of derivatives and there is typically more hedging of liabilities than assets, this means we are missing the fact that they are even more long foreign currency than our estimates. ${ }^{5}$ Thus, we are biasing our estimates towards zero; the exposure is not being hedged away. It is also worth noting that, for non-financial center countries, the estimated net international derivatives positions are typically less than 1 percent of GDP, meaning that cross-border net gains and losses on derivatives will necessarily tend to be small relative to other sources of net valuation gains and losses.

Second, one might worry about onshore issuance of foreign currency liabilities. These keep the exposure within a country, though, creating both a short and long position within the same country, which does not have an impact on the aggregate international balance

\footnotetext{
${ }^{5}$ See Becker and Fabbro (2006) for a study of hedging in Australia, which shows that Australia is a net purchaser of currency insurance from foreign investors, or Hau and Rey (2006) who estimate that only 10 percent of foreign equity positions are hedged.
} 
sheet. Finally, in some cases, a corporation in country A may be hurt by foreign-currency losses of a subsidiary in country B. These are problems we cannot address with available data. $^{6}$

Despite all these concerns, as shown in Lane and Shambaugh (2010a), the estimated VALXR is a strong predictor of the overall VAL effects.

In summary, this section has laid out the key concepts and measurement methods required to analyse the international finance impact of exchange rate movements. In the next section, we report some primary features of the assembled dataset, with the main focus on the 2002-2012 period that encompasses the pre-crisis period (2002-2007), the acute phase of the global crisis (2008-2009) and the post-crisis phase (2010-2012).

\section{Stylised Facts}

This section describes the evolution of aggregate and bilateral international currency exposures. In addition, it traces out the scale of $V A L X R$ over 2002-2012 and conducts some counterfactual exercises.

To the extent that a country depreciates after a negative shock, there is an advantage to a net long position in foreign currency, since it acts as a hedge against asymmetric shocks (Lane and Shambaugh 2010b). Lane and Shambaugh (2010a) showed that the net foreign currency position improved markedly for many countries from the mid-1990s to 2004. Here, we extend that analysis to demonstrate the continued shift in the run-up to the global financial crisis. Figure 1 shows the cumulative cross-country distribution of FXAGG positions in 1996, 2002, 2007 and 2012. The marked shift to the right demonstrates the extent to which fewer countries over time maintained short foreign currency positions. $^{7}$ While 65 percent of countries had negative $F X A G G$ values in 1996, only 61

\footnotetext{
${ }^{6}$ Under this scenario, country A would experience losses on its FDI position in country B since the foreign-currency losses incurred by the foreign subsidiary would reduce the value of the parent company's claim on the subsidiary.

${ }^{7}$ While at the investor level, one might think that the exposure to a given currency around the world must be balanced (if someone is short, someone else is long), that is not true at the country level. If the United States sells dollar assets abroad, that does not represent a foreign currency liability for the US
} 
percent of countries had negative $F X A G G$ values by 2002, further declining to 36 percent by 2007 . This trend changed direction in a minor way after the crisis, with 41 percent of countries exhibiting negative $F X A G G$ by 2012.

The shift is even starker in relation to severely-negative $F X A G G$ values: 38 percent of countries had values below minus 0.3 in 1996 but this had dropped to 28 percent by 2002 and just 6 percent by 2007. On the eve of the global financial crisis, very few countries were highly exposed to an idiosyncratic depreciation in they way they had been just a decade earlier. Accordingly, the stereotype of the typical emerging market economy suffering from a high net dependence on foreign-currency liabilities looks quite outdated. As we document below, this had a distinct advantage during the global financial crisis, since economies with improved net foreign currency positions could better tolerate currency depreciations during this period.

The improvements in FXAGG values were most dramatic for emerging market and developing economies, with advanced economies experiencing a smaller increase (see Table 1). ${ }^{8}$ The median advanced country moves from a $F X A G G$ of 0.07 to 0.08 , an almost imperceptible shift while emerging and developing economies shift from a median of -0.30 to positive 0.05. Indeed, it may be surprising to some that $F X A G G$ values were the same for the two groups. In fact, for emerging countries only, the median is even more positive than for the advanced group by 2007, although that ranking may be interpreted as consistent with greater underlying vulnerability to currency and financial shocks in the former group. The improvement in the $F X A G G$ value for emerging and developing countries was driven by two main factors. First, a sequence of current account surpluses meant an improvement in the ratio of foreign assets to foreign liabilities. Second, there was a shift in the composition of foreign liabilities, with foreign-currency debt liabilities replaced by equity-type liabilities. ${ }^{9}$

but it is a foreign currency asset from the viewpoint of the foreign investors holding the claims. For this reason, countries can in aggregate be either long or short foreign currency.

${ }^{8}$ As highlighted by Lane and Shambaugh (2010a), there are large differences within the advanced group, especially between the euro area and other advanced countries. In particular, the foreign assets and foreign liabilities of euro area member countries are largely denominated in euro.

${ }^{9}$ The issuance of domestic-currency debt liabilities to foreign investors was only a minor contributor 
Lane and Shambaugh (2010b) documented a number of key covariates of foreign exchange exposure. The aggregate net international investment position is the key factor in determining whether a country is long or short foreign currency. For a given net international investment position, the distribution of the non-reserve position is especially influential (in particular, the share of portfolio equity and FDI in foreign liabilities). For emerging and developing countries, the level of reserves is also an important explanatory variable in the variance decomposition of the $F X A G G$ positions. ${ }^{10}$

As to what fundamental factors correlate with these positions, Lane and Shambaugh (2010b) analysed the risk characteristics and institutional factors that might influence the cross-country variation in $F X A G G$. We extend this analysis to include the more recent data points in Table 2 by running regressions of the form

$$
\begin{aligned}
F X A G G_{i t}= & \beta_{0} T R A D E_{i t}+\beta_{1} S I Z E_{i t}+\beta_{2} V O L_{i t}+\beta_{3} C O V_{i t}+ \\
& \gamma Z_{i t}+\lambda G D P_{i t}^{P C}+\theta Y_{t}+\varepsilon_{i t},
\end{aligned}
$$

where $T R A D E_{i t}$ is trade openness; $S I Z E_{i t}$ is $(\log )$ population; $V O L_{i t}$ is a vector including three volatility measures: the standard deviation of real GDP growth, inflation and the nominal effective exchange rate (over a fifteen year window); $C O V_{i t}$ is the covariance between GDP growth and the change in the nominal effective exchange rate; the vector $Z_{i t}$ includes indicators for the quality of institutions and capital account openness and dummy variables for exchange rate peggers and EMU members; $G D P_{i t}^{P C}$ is (log) GDP per capita; and, finally, $Y_{t}$ are a set of dummy variables for 1996, 2000, 2004, 2007 and $2012 . .^{1112}$

In column (1) of Table 2, we run a narrow specification and find similar results to Lane

to the overall shift.

${ }^{10}$ Reserves and private positions tend to be positively correlated in emerging and developing countries and have a roughly zero correlation in advanced economies.

${ }^{11}$ Accordingly, we exclude the constant from the estimation.

${ }^{12}$ See, in particular, Table 4 of Lane and Shambaugh (2010b). 
and Shambaugh (2010b): more open and larger economies and those that depreciate in bad times tend to have more positive positions and those with more volatile exchange rates have more negative positions. Once the institutional and policy controls are included in column (2), the coefficients on exchange rate volatility and the covariance between output and the exchange rate shrink in size and lose statistical significance, while the volatility of GDP and inflation turn significantly positive (more volatile output and inflation rates are associated with more positive foreign currency positions). ${ }^{13}$ As in the previous work, countries with better institutions are long foreign currency and those in the euro area have more negative positions, while capital controls are also associated with more positive positions.

The (log) level of GDP per capita is an alternative general control variable, since so many institutional and policy variables are systematically correlated with the level of development. In columns (3) and (4), there is a strongly positive correlation between FXAGG and GDP per capita, while column (4) shows that the inclusion of GDP per capita results in the loss of individual significance for trade openness, institutional quality and capital controls, while the peg variable turns marginally significant. Finally, the time dummies for 2004, 2007 and 2012 are each significantly positive, capturing the general shift towards more positive $F X A G G$ variables over the latter part of the sample period. ${ }^{14}$

Next, we turn to the evolution of NETFX values. As was shown in equation (13), the $N E T F X$ variable is just the $F X A G G$ index multiplied by the $I F I$ ratio (the ratio of the sum of foreign assets and foreign liabilities to GDP) - it expresses the stock of net foreign currency assets as a ratio to GDP. This shows not just the vulnerability of the external balance sheet to uniform exchange rate movements, but also how exposed is an economy to shifts in foreign currency values. That is, a country can be exposed either

\footnotetext{
${ }^{13}$ The volatility of inflation was not significant in the earlier sample studied by Lane and Shambaugh (2010a).

${ }^{14}$ Replications of regressions of changes in $F X A G G$ over the sample (not shown) no longer find the previous result that countries have seen an increase in the correlation of GDP and the exchange rate (that is, are now more likely to depreciate in bad times) shift towards a longer foreign currency position. It could be that the shift took place more in the 1996-2004 sample examined previously, or that the shocks from 2008-2012 have changed the correlations of GDP and exchange rates in ways that are not related to changing $F X A G G$ positions.
} 
because of a highly-asymmetric currency portfolio on its balance sheet or due to a very large balance sheet even with relatively close currency matching. ${ }^{15}$

For emerging markets and developing economies, the trend in NETFX is very similar to $F X A G G$, since the scale of international balance sheets for these groups remained relatively stable over this interval, as shown in Figure 2. It is notable that the median IFI for emerging and developing countries shows a relatively flat increase in the scale while the median for advanced countries climbs significantly, rising to considerably more than four times GDP.

Table 1 highlights the striking feature that there has been a large increase in the $N E T F X$ value for advanced economies despite the minor change in the FXAGG index for this group. Since the overall holdings of foreign assets and foreign liabilities expanded so rapidly during this period, the combination of a relatively-stable currency mix and an expansion in the total scale of the international balance sheet mapped into a much larger net foreign currency position relative to GDP for the typical advanced economy.

In this sense, the build-up of gross positions - not just net positions - was quite important to the growing exposure of these countries to changes in foreign currency. With this combination, unanticipated currency depreciation (as experienced by advanced countries such as the United Kingdom, Australia and New Zealand during the global crisis) conferred a much larger net valuation gain during this episode relative to historical norms, but countries that appreciated in the crisis (or that held large positive positions in the depreciating currencies) faced substantial losses.

We can summarize this shift over time by examining the 75 th and 25 th percentiles of the NETFX distribution as in Figure 3. We see that few countries are short foreign currency in considerable amounts, but this does not mean that few countries are exposed to foreign currency movements. The large scale of NETFX seen in the rising value for the 75 th percentile means that shifts across currencies could lead to large valuation effects. These aggregate measures were the focus of Lane and Shambaugh (2010a, 2010b), which

\footnotetext{
${ }^{15}$ As documented by Bénétrix (2009), sizable gross positions can be associated with large valuation episodes.
} 
focused on the implications for an individual economy of a uniform shift in its currency against all other currencies. However, the global financial crisis saw wide swings across many currency pairs, suggesting the specific makeup of currency exposure could be quite important in determining the overall valuation impact.

For this reason, we now turn to examine bilateral currency exposures. We focus on the weights against the dollar, euro, pound, swiss franc, and yen as well as the aggregate of all other currencies. Figure 4 shows the distribution of the currency weights across countries for each of the five major global currencies, while Figure 5 shows the distribution for the holding of all other currencies as well as the aggregate for the five global currencies.

A number of general features stand out from Figures 4 and 5. First, almost no countries are short non-global currencies. That is, almost no country borrows in a minor currency other than their own. We can see this in Figure 5, which shows that many countries have a zero weight on non-global currencies, while around 15 percent of the distribution have moderately large positive positions (for example, Western European countries with significant FDI positions in Central and Eastern Europe). As seen in Figure 4, almost no countries are short in Sterling. Some countries had accumulated short positions in yen (likely due to carry trade activity that was funded in yen markets). Almost no countries are long yen (the JGB market is well known for its domestic bias) but around 20 percent have at least a moderate short position.

There are much larger positions against the dollar and the euro, with many countries substantially short against the dollar. Over a quarter of countries have a weight of at least -0.1 on the dollar, and well over 10 percent of the distribution is short by at least a -0.2 weight. Thus, while only 36 percent of countries were net short foreign currency in the aggregate, more (over 48 percent) were short the dollar. ${ }^{16}$

While many countries are short dollars, on aggregate the world should be long dollars. The U.S. both borrows and lends in dollars, but as its long running current account deficit

\footnotetext{
16 The role of the dollar as an international funding currency has been extensively studied, with "dollar shortages" a major problem for European banks during the global financial crisis. Within the dollar component, a number of advanced economies have short positions in relation to debt instruments and long positions in relation to equity instruments.
} 
and accumulated negative NIIP position show, it borrows more than it lends. Hence there should be more dollar foreign assets held abroad than dollar foreign liabilities abroad. The fact that much of the U.S. lending is in the form of buying foreign-currency foreign assets simply widens this gap. Note that any trade in dollars between non-US residents simply nets out in the world's balance sheet. Japan on the other hand has a small foreign liability position, suggesting few yen assets around the world relative to the yen liabilities as some investors have borrowed in yen (as part of the carry trade). In our sample - which is missing a number of Gulf State oil exporters - the world is slightly short dollars (along with yen and Swiss francs), while long in Sterling and euro.

Given these exposures and the rapid scale of exchange rate movements in 2008-2009, it is not surprising that there were substantial valuation effects in the crisis. Figure 6 shows both the large and sharply negative $V A L X R$ in 2008 relative to other periods. In the two years immediately preceding the crisis, the 10th percentile of countries faced losses of 2.6 and 2.0 percent of GDP, while this jumped to 6.8 percent in 2008. As seen in Table 3 , the average value of $V A L X R$ went from being less than one percent of GDP in the years before (and after) 2008 to -1.8 percent of GDP in 2008. This was not just due to a few outliers. The median value jumped to -1.7 percent of GDP and the 25 th percentile was -4 percent of GDP, suggesting substantial losses for a large number of countries.

Simply looking at scale and not sign, we can see $V A L X R$ was much larger in the crisis than in a typical year. The inter-quartile range of the absolute value of $V A L X R$ jumps from $(0.5,2.2)$ to $(1.0,5.2)$. That is, 25 percent of countries faced gains or losses due to exchange rate movements of at least 5.2 percent of GDP. Perhaps more surprising is that the valuation effects were strikingly negative in 2008. While only 36 percent of countries were short foreign currency in aggregate in 2007, not only were median or average losses large, over 67 percent of countries faced currency-generated valuation losses.

In terms of the largest absolute gains and losses, Table 4 shows the top five countries in each category. The United Kingdom and Canada stand out in terms of receiving the largest currency-generated valuation gains, while Japan and the United States endured 
the largest losses in absolute terms. ${ }^{17}$

Table 5 shows the distribution of valuation gains and losses in 2008 relative to foreign currency exposure and exchange rate movements. Fifty countries in some sense match the classic story of a depreciation. Twenty-two countries were long foreign currency and depreciated against both asset and liability indices and hence had $V A L X R$ gains. Twenty-eight countries were short foreign currency, depreciated and faced $V A L X R$ losses. Another twenty countries had appreciations: three countries were short foreign currency and thus benefited from an appreciation, while thirteen countries were long foreign currency and hence lost when their currencies strengthened (including the United States, Japan and Switzerland).

The other countries highlight the importance of the mix of currencies on the balance sheet. These were long foreign currencies in aggregate, but had negative $V A L X R$. Twenty depreciate against their liability index but appreciate against their assets. This implies they were holding exactly the opposite portfolio of what would have been preferred in the crisis. The others had depreciations against both indices, but had negative valuation shocks due to their portfolio mix. In many ways, the crisis was the perfect storm to generate losses. The currencies that much of the world was short (the dollar and the yen) appreciated sharply while other currencies weakened. While countries that were long foreign currency in the aggregate were safe against an idiosyncratic depreciation, those that were short "safe haven" currencies (such as the US dollar) lost in the global crisis. While the dollar had been depreciating in the first half of 2008, its sharp appreciation in the crisis meant that the average annual depreciation against the dollar was 10 percent in 2008, while the average depreciation against the yen was over 35 percent. On the other side, Sterling depreciated 20 against the average currency. Thus, significant losses could result from even moderate short positions against the yen or the US dollar or long positions in Sterling.

\footnotetext{
${ }^{17}$ While there is little other work that can provide a direct check on our estimates, there are a few estimates of individual country's valuation gains or losses over the last few years (we thank Bob McCauly for pointing out some of these). Our estimates always have the same sign, and generally a similar magnitude. In cases where the estimates differ, our estimation method tends to be far more detailed.
} 
These substantial losses were partially reversed in 2009, as exchange rates swung back in some cases after March 2009. This can in part be seen by the fact that the typical valuation effects in 2009 swing sharply positive after the heavily negative effects in 2008 . Figure 7 shows the scatter of $V A L X R$ in 2008 and 2009. A number of countries lie on the negative 45 degree line suggesting that losses or gains in 2008 were reversed a year later. Lane and Shambaugh (2010a) showed that $V A L X R$ was not a negatively autocorrelated series over 1990-2004. In general, a loss in one year was not reversed the following year. From 2002 to 2008, the average autocorrelation for $V A L X R$ was 0.18. The autocorrelation in 2009 however jumps to -0.39 , suggesting some (though not complete) reversal from the very large shocks in 2008.

Importantly, 2010 is also a year with negative autocorrelation, indicating some of the rebound effect in 2009 was washed away the following year such that in the end there were indeed cumulative valuation effects. Figure 8 shows the cumulative $V A L X R$ for the 10th, 25th, 75th and 90th percentiles over the period 2008-2012. As shown earlier, the 25th percentile in 2008 alone was -4 percent of GDP. Over the whole period, it is also -4 percent of GDP. Thus, a quarter of countries faced a nontrivial loss that did not reverse.

While the losses and, in some cases, gains were large, these could have been much larger had it not been for the shifts in portfolios in the years prior to the crisis. Figure 9 shows the counterfactual distribution of $V A L X R$ for the same exchange rate change as was experienced in the crisis. That pattern of exchange rate changes is considered against three different balance sheets. First, the actual positions in 2007, second the positions in 2002, and third the positions in 1996 (prior to the Asian financial crisis). Well over 80 percent of countries would have faced losses if the 1996 or 2002 exposure patterns still applied. ${ }^{18}$ Moreover, over 10 percent of countries would have lost at least 10 percent of

\footnotetext{
${ }^{18} \mathrm{It}$ is interesting that the distribution for 1996 and 2002 is quite similar. This is explained by the fact that offsetting developments over that interval canceled out. Countries had less negative FXAGG positions by 2002 , but the balance sheets were much larger. If one examines the same $F X A G G$ as were realized in 2002 and 1996, but uses the same balance sheet size as in 2007, the losses in 1996 would have been much larger.
} 
GDP and 30 percent of countries would have lost at least 5 percent of GDP. This does not even include the fact that as losses mounted, countries may have depreciated even more sharply against the dollar and yen in which cases losses would have been even larger. In short, had countries not shifted to a more positive foreign currency position, the crisis could have been much worse.

We next turn to examine not just the size, but the general properties of $V A L_{i t}^{X R}$ in the crisis.

\section{Empirical Analysis}

In this section, we ask whether $V A L X R_{i t}$ played a stabilising role during the global financial crisis or, alternatively, contributed to crisis propagation by generating negative wealth effects. In terms of the cross-country distribution, we examine

$$
V A L X R_{i t}=\alpha+\beta Z_{i t}+\varepsilon_{i t}
$$

where $Z_{i t}$ represents a vector of macro-financial variables. In relation to external adjustment, we can ask whether $V A L X R_{i t}$ during the crisis was correlated with measures of pre-crisis external imbalances, as captured by the pre-crisis levels of the net international investment position and the current account balance. ${ }^{19}$ If those countries with the most severe negative pre-crisis positions enjoyed the largest currency-induced valuation gains during the crisis, this would be a stabilising pattern in the sense of compressing the distribution of external imbalances. Alternatively, if the opposite pattern held, the distribution of $V A L X R$ in 2008 would been a destabilising factor, in the sense of contributing to a widening of external imbalances.

In addition to its role in external adjustment, $V A L X R_{i t}$ may also be relevant in

\footnotetext{
${ }^{19}$ We also examined the $C A G A P$ measure of "excessive" imbalances developed by Lane and MilesiFerretti $(2012,2014)$. The results were generally similar with this alternative measure, which is only available for a smaller set of countries. Lane and Milesi-Ferretti (2014) show an inverse (stabilising) relation between pre-crisis external imbalances and the overall stock-flow adjustment term over 20082012.
} 
relation to macroeconomic adjustment and financial adjustment, since a positive external wealth shock $\left(V A L X R_{i t}>0\right)$ can provide some buffering in the event of negative domestic shocks (such as declines in domestic output or domestic asset prices). In relation to the former, we examine the covariation between $V A L X R_{i t}$ and growth in output during the crisis. In relation to the latter, we look at its relation with stock returns and long-term interest rates.

Tables 7 and 8 show the results. In Table 7, we run equation (16) for the full sample and the advanced and emerging/developing subsamples. In addition, we also run the regressions for a restricted sample that excludes very small and very poor countries (total dollar GDP below $\$ 20$ billion), on the presumption that these countries are more likely to suffer from data quality issues. ${ }^{20}$

In the full sample and the emerging/developing subsample, the regressors are typically not individually significant. ${ }^{21}$ However, there is some evidence of a stabilising role for $V A L X R$ vis-à-vis the net international investment position for the advanced subsample in columns (4) and (5) of Table 7. At the same time, in the opposite direction, there is a destabilising positive relation between the current account balance and $V A L X R$ for this group. ${ }^{22}$ None of the other regressors are significant for the advanced subsample.

Table 8 reports estimates for additional subsamples, where countries are divided between non-peggers and peggers. ${ }^{23}$ This may be a relevant sample split to the extent that a stronger correlation between exchange rate movements and macro-financial fundamentals might be expected for the non-peggers than the peggers. Indeed, the only evidence of a stabilising pattern vis-à-vis the net international investment position is for the non-pegger group in column (2) of Table $8 .{ }^{24}$ However, even that result is sensitive to the removal of

\footnotetext{
${ }^{20}$ See also Lane and Milesi-Ferretti $(2012,2014)$ on the selection of the high-quality sample.

${ }^{21}$ The one exception is a positive coefficient on the domestic stockmarket return in for the full sample in column (2) and (3) of Table 7. This pattern is also found for the non-pegger sample in columns (2)-(4) of Table 8. However, this is a destabilizing pattern in that the countries experiencing the worst stockmarket returns are also experiencing currency-related valuation losses.

${ }^{22}$ This also holds if the $C A G A P$ variable is included as an alternative to the unadjusted current account balance.

${ }^{23}$ We follow Shambaugh (2004) in this classification.

${ }^{24}$ Again, the domestic stockmarket return is positive and statistically significant for most subsamples.
} 
an extreme value (Singapore) in columns (3) and (4).

Taken together, Tables 7 and 8 provide some evidence of a limited role for $V A L X R$ in stabilising the cross-country distribution of net international investment positions. At the same time, this pattern is not overly robust and there is little covariation between $V A L X R$ and the other macro-financial variables included in the regression. Perhaps this should not be too surprising, in view of the large literature that underlines the limited connection between currency movements and macro-financial fundamentals, especially over short horizons. ${ }^{25}$

Tables 9 and 10 reprise the analysis for the cumulative exchange rate valuation effects for 2008-2012. The patterns in Table 9 are similar to those in Table 7 but the correlations are weaker. The negative relation between the pre-crisis net international investment position is only marginally significant for the advanced country group in column (4) of Table 9, while there is no pattern in the EMDEV sample.

When splitting the sample by exchange rate regime in Table 10, however, there is one interesting finding. As in Table 8, the non-pegged sample has statistically significant coefficients if Singapore is included, though the coefficients are similar and close to significant with both a stabilizing (negative) coefficient for NFA but destabilizing (positive) coefficient for the current account. Now, though, the pegged sample actually has a positive coefficient on $N F A$ in 2007 meaning that, amongst pegged countries, those with positive net foreign asset positions were the ones that experienced the most positive $V A L X R_{i t}$ effects. $^{26}$ This results suggests that pegging may not only prevent a country from depreciating to help clear external imbalances through a trade channel, but it may make it more difficult for a country to experience valuation gains in a crisis that could help remedy an accumulated negative $N F A$ position. In relation to domestic variables, the results in column (5) do suggest a negative relation between output growth and $V A L X R$ (which is a stabilising pattern), even if there is a positive relation between the domestic

\footnotetext{
${ }^{25}$ See also Lane and Milesi-Ferretti (2012, 2014) and Rose (2014).

${ }^{26}$ This effect is marginally significant in column (7) of Table 8 for the high quality sample of peggers in 2008 .
} 
stockmarket return and $V A L X R$.

Finally, we examine the relation between $V A L X R_{i t}$ and the overall stock-flow adjustment term $\left(V A L_{i t}\right)$ in 2008. ${ }^{27}$ Lane and Shambaugh (2010a) showed that there was a large positive correlation between the overall valuation effect and the exchange rate valuation effects. The connection is not mechanical. The exchange rate valuation effects are calculated based on currency weights, balance sheet size, and exchange rate changes, while the overall valuation effect is simply the change in the net foreign asset position not explained by current accounts. Thus, the coefficients of over 0.5 in a regression of $V A L_{i t}$ on $V A L X R_{i t}$ in that paper was in some ways surprising. Figure 10 shows scatter plots for the advanced and emerging/developing groups, and it demonstrates that very strong positive correlation does not hold in the turbulent year of 2008. While it is possible to identify individual countries in which $V A L X R$ accounts for a substantial proportion of the overall $V A L_{i t}$ value, there is a weaker cross-country correlation for 2008 . The correlations are positive, but in the 0.15-0.2 range, much less than the coefficients in the 1994-2004 period. The large-scale shifts in asset prices (most obviously, equity market indices) in 2008 means that currency-related valuation effects were dominated by market-related valuation effects in many countries.

Regressions of VAL on VALX (after having dropped the top and bottom 1\% outliers) for the full sample have a coefficient of 0.59 (statistically significantly different from zero at the $99 \%$ level) while for $2007-12$ it is 0.38 (also different from zero at the $99 \%$ level). Looking at regressions across countries for individual years, 2008, 2009, and 2010 have the 2nd, 3rd, and 4th lowest coefficients (all between 0.2 and 0.3), but 2011 and 2012 rebound to the typical range. Thus, it appears other factors had strong influences on the overall VAL terms during the 2008-2010 crisis, but VAL and VALX are consistently positively correlated, and outside the crisis, quite strongly so. As in Lane and Shambaugh (2010a), the coefficients tend to be much higher in the emerging and developing sample, for advanced countries, the overall coefficient is 0.27 while in recent times it is just 20 .

\footnotetext{
${ }^{27}$ As noted in Section 2, we do not have data on $V A L$ and $N E T O T H$ separately, so we use the overall $S F A$.
} 
For emerging and developing countries, the respective coefficients are 0.56 and 0.28 . Some of the drop in the coefficient in the 2007-12 period (in all 3 samples), though, appears to be due to a few large shocks. If we drop the top and bottom $5 \%$ of observations instead of just top and bottom 1\%, the coefficient for 2007-2012 is not statistically different than that for 1997-2012.

\section{Conclusions}

This paper has analysed the recent evolution of international currency exposures, with a special focus on currency-generated valuation effects during the global financial crisis. To this end, we described some key features in an updated and extended dataset on international currency positions over 1990-2012. We highlighted the "normalisation" of foreign currency exposure patterns, with a trend decline in the number of countries running large short foreign-currency positions. At the same time, the increase in the scale of international balance sheets (especially for advanced economies) means that a given exchange rate shift can now generate much larger cross-border wealth effects relative to GDP.

The global financial crisis represents an important testing ground in understanding the distribution of currency-generated valuation effects. Our analysis finds that the scale of these effects were large in 2008 relative to the pre-crisis years and were quite persistent over the 2008-2012 period. Moreover, we find that the exact composition of foreign currency positions mattered during the crisis, with those countries short in US dollars and yen and/or long in Sterling suffering the largest currency-induced valuation losses.

In terms of their contribution to macro-financial stabilisation, there is some limited evidence that currency-based valuation effects moved inversely to pre-crisis net international investment positions (though not for fixed exchange rate countries). However, that pattern is sensitive to the sample selection and there is little covariation with other macro-financial fundamentals, so that the broader message is that the valuation impact of exchange rate movements is largely orthogonal to other factors. In this sense, our 
analysis is in line with the large literature on the disconnect between exchange rates and macro-financial fundamentals.

\section{Data Appendix}

\section{Country list}

- Advanced countries (22): Australia (AUS), Austria (AUT), Belgium (BEL), Canada (CAN), Denmark (DNK), Finland (FIN), France (FRA), Germany (DEU), Greece (GRC), Iceland (ISL), Ireland (IRL), Italy (ITA), Japan (JPN), Netherlands (NLD), New Zealand (NZL), Norway (NOR), Portugal (PRT), Spain (ESP), Sweden (SWE), Switzerland (CHE), United Kingdom (GBR) and United States (USA)

- Emerging market economies and developing countries (95): Albania (ALB), Algeria (DZA), Argentina (ARG), Armenia (ARM), Azerbaijan (AZE), Bangladesh (BGD), Belarus (BLR), Benin (BEN), Bolivia (BOL), Bosnia and Herzegovina (BIH), Botswana (BWA), Brazil (BRA), Burkina Faso (BFA), Cambodia (KHM), Cameroon (CMR), Chad (TCD), Chile (CHL), China (CHN), Colombia (COL), Congo, Rep. (COG), Cote d'Ivoire (CIV), Croatia (HRV), Czech Republic (CZE), Dominican Republic (DOM), Egypt (EGY), El Salvador (SLV), Equatorial Guinea (GNQ), Estonia (EST), Ethiopia (ETH), Fiji (FJI), Gabon (GAB), Georgia (GEO), Ghana (GHA), Guatemala (GTM), Guinea (GIN), Haiti (HTI), Honduras (HND), Hong Kong (HKG), Hungary (HUN), India (IND), Indonesia (IDN), Iran (IRN), Israel (ISR), Jamaica (JAM), Jordan (JOR), Kazakhstan (KAZ), Kenya (KEN), Korea, Republic of (KOR), Kyrgyz Republic (KGZ), Latvia (LVA), Lithuania (LTU), Macedonia, FYR (MKD), Madagascar (MDG), Malawi (MWI), Malaysia (MYS), Mali (MLI), Mexico (MEX), Moldova (MDA), Morocco (MAR), Mozambique (MOZ), Nepal (NPL), Nicaragua (NIC), Niger (NER), Nigeria (NGA), Oman (OMN), Pakistan (PAK), Papua New Guinea (PNG), Paraguay (PRY), Peru (PER), Philippines (PHL), Poland (POL), Romania (ROM), Russian Federation (RUS), Rwanda (RWA), Senegal (SEN), Singapore (SGP), Slovak Republic (SVK), Slovenia (SVN), South Africa (ZAF), Sri Lanka (LKA), Syrian Arab Republic (SYR), Tanzania (TZA), Thailand (THA), Togo (TGO), Trinidad and Tobago (TTO), Tunisia (TUN), Turkey (TUR), Turkmenistan (TKM), Uganda (UGA), Ukraine (UKR), Uruguay (URY), Venezuela (VEN), Vietnam (VNM), Yemen, Republic of (YEM) and Zambia (ZMB) 


\section{Differences with Lane and Shambaugh (2010a)}

The dataset used here is an update of Lane and Shambaugh (2010a). That data originally covered the period 1990 to 2004. Here, we extend it to 2012. The empirical methodologies to estimate the currency of denomination of the various IIP items are the same as before. Improvements are mainly related to the use of more up-to-date data releases. This means that data revisions going back in time are taken into account in this version. For instance, we use the latest IMF Coordinated Portfolio Investment Survey (CPIS) and Lane and External Wealth of Nations (Milesi-Ferretti 2007) data. In terms of the Foreign Direct Investment component, this version also uses the new Coordinated Direct Investment Survey (CDIS) from the IMF. We take these for the 2009-2012 period. Before 2009 we continue using United Nation's UNCTAD data. Locational BIS bank debt data are a newer version that includes a larger number of reporter countries. The new additions are Canada, Denmark, Greece, India, Indonesia and Korea. Finally, we have improved the estimates for the currency composition of Japanese portfolio debt assets using balance of payments data from the Bank of Japan. As a result, Japanese currency distribution of portfolio debt asset is allowed to vary in time from 2005 onwards. In terms of the overall dataset, the necessary adjustments have been implemented to account for the fact that Slovenia, Slovakia and Estonia joined the Eurozone after 2004.

\section{Other data and sources}

Here, we give details on the variables used in the econometric analysis section and their sources. Real GDP growth is from the International Monetary Fund's (IMF) World Economic Outlook Database 2014. Stock-flow adjustment, net foreign assets and current account balance data are from the latest version of the External Wealth of Nations dataset (Lane and Milesi-Ferretti 2007). The source for stock market returns is MSCi Barra and national sources, while long term interest rates are taken from IMF's International Financial Statistics (IFS) data base and from national sources. Exchange rate regime data (peg and no peg) are from Klein and Shambaugh (2008). Trade openness, population, and per capita income are taken from World Bank's (WB) World Development Indicators. Nominal effective exchange rate (NEER) is sourced from IMF's IFS and Bank for International Settlements. The source for consumer price index (CPI) and nominal exchange rate is IMF's IFS; World Governance Indicators from World Bank; and Capital Account Openness from Chinn-Ito's website 


\section{References}

Acharya, Viral V. and Philipp Schnabl (2010), "Do Global Banks Spread Global Imbalances? Asset-Backed Commercial Paper During the Financial Crisis of 2007-09," IMF Economic Review 58 (1), 37-73.

Ahmed, Shaghil and Andrei Zlate (2013), "Capital Flows to Emerging Market Economies: A Brave New World?," International Finance Discussion Paper No. 1081, Board of Governors of the Federal Reserve System.

Becker, Chris and Daniel Fabbro (2006), "Limiting Foreign Exchange Exposure through Hedging: The Australian Experience," Reserve Bank of Australia Research Discussion Paper No. 2006-09.

Bénétrix, Agustín S. (2009), "The Anatomy of Large Valuation Episodes," Review of World Economics 145(3): 489-511.

Blanchard, Olivier (2007), "Current Account Deficits in Rich Countries," IMF Staff Papers 54(2), 191-219.

Bruno, Valentina and Hyun Song Shin (2013), "Capital Flows, Cross-Border Banking and Global Liquidity," NBER Working Paper No. 18942.

Calderon, Cesar and Megumi Kubota (2012), "Gross Inflows Gone Wild: Gross Capital Inflows, Credit Booms and Crises," World Bank Policy Research Working Paper No. 6270 .

Catao, Luis and Gian Maria Milesi-Ferretti (2013), "External Liabilities and Crises," IMF Working Paper No. 13-113.

Cetorelli, Nicola and Linda S. Goldberg (2012), "Banking Globalization and Monetary Transmission," Journal of Finance 67(5), 1811-1843.

Curcuru, Stephanie E., Tomas Dvorak and Francis E. Warnock (2008), "Cross-Border Returns Differentials," Quarterly Journal of Economics 123(4), 1495-1530.

Curcuru, Stephanie E., Charles P. Thomas and Francis E. Warnock (2013), "On Returns Differentials," Journal of International Money and Finance 36, 1-25.

Eichengreen, Barry, Ricardo Hausmann and Ugo Panizza. 2003. Currency Mismatches, Debt Intolerence and Original Sin: Why They Are Not the Same and Why it Matters. National Bureau of Economic Research Working Paper 10036. 
Eichengreen, Barry, and Ricardo Hausmann. 2005. Other People's Money: Debt Denomination and Financial Instability in Emerging Market Economies. Chicago, IL: University of Chicago Press.

European Commission (2010), "The Importance of Valuation Effects for External Asset Positions in the Euro Area," Quarterly Report of the Euro Area 9(1), 29-36.

Gohrband, Christopher A.and Kristy L. Howell (2014), "U.S. International Financial Flows and the U.S. Net Investment Position: New Perspectives Arising from New International Standards," in Measuring Wealth and Financial Intermediation and Their Links to the Real Economy (Charles Hulten and Marshall Reinsdorf, editors), University of Chicago Press, forthcoming.

Goldstein, Morris, and Philip Turner. 2004. Controlling Currency Mismatches in Emerging Markets. Washington, DC: Institute for International Economics.

Gourinchas, Pierre-Olivier and Maurice Obstfeld (2012), "Stories of the Twentieth Century for the Twenty-First," American Economic Journal: Macroeconomics 4(1), 226-265.

Gourinchas, Pierre-Olivier, and Helene Rey (2007), "International Financial Adjustment." Journal of Political Economy 115, 665-703.

Gourinchas, Pierre-Olivier and Helene Rey (2013), "External Adjustment, Global Imbalances and Valuation Effects," NBER Working Paper No. 19240.

Gourinchas, Pierre-Olivier, Helene Rey and Kai Truempler (2012), "The Financial Crisis and The Geography of Wealth Transfers," Journal of International Economics 88(2), 266-285.

Klein, Michael W. and Jay C. Shambaugh (2008), "The Dynamics of Exchange Rate Regimes: Fixes, Floats, and Flips," Journal of International Economics 75(1), 7092.

Hau, Harald, and Hélène Rey (2006), "Exchange Rates, Equity Prices, and Capital Flows," Review of Financial Studies 19(1), 273-317.

Kubelec, Chris and Filipa Sa (2012), "The Geographical Composition of National External Balance Sheets: 1980-2005," International Journal of Central Banking 8(2), 143-189.

Lane, Philip R. (2012), "The Dynamics of Ireland's Net External Position," Journal of the Statistical and Social Inquiry Society of Ireland XLI, 24-34, 2012. 
Lane, Philip R. (2013a), "Capital Flows in the Euro Area," European Economy Economic Paper No. 497.

Lane, Philip R. (2013b), "Financial Globalisation and the Crisis," Open Economies Review 24(3), 555-580.

Lane, Philip R. and Gian Maria Milesi-Ferretti (2007a), "The External Wealth of Nations Mark II," Journal of International Economics 73, 223-250.

Lane, Philip R. and Gian Maria Milesi-Ferretti (2007b), "Europe and Global Imbalances," Economic Policy 22(51), 519-573.

Lane, Philip R. and Gian Maria Milesi-Ferretti (2008), "The Drivers of Financial Globalization," American Economic Review 98(2), 327-332.

Lane, Philip R., and Gian Maria Milesi-Ferretti (2008) "International Investment Patterns," Review of Economics and Statistics 90(3), 538-549.

Lane, Philip R., and Gian Maria Milesi-Ferretti (2009), "Where Did All the Borrowing Go? A Forensic Analysis of the U.S. External Position" Journal of Japanese and International Economies 23(2), 177-199.

Lane, Philip R. and Gian Maria Milesi-Ferretti (2011), "The Cross-Country Incidence of the Global Crisis," IMF Economic Review 59, 77-110.

Lane, Philip R. and Gian Maria Milesi-Ferretti (2012), "External Adjustment and the Global Crisis," Journal of International Economics 88(2), 252-265.

Lane, Philip R. and Gian Maria Milesi-Ferretti (2014), "Global Imbalances and External Adjustment After the Crisis," IMF Working Paper No. 14-151.

Lane, Philip R. and Peter McQuade (2014), "Domestic Credit Growth and International Capital Flows," Scandinavian Journal of Economics, forthcoming.

Lane, Philip R. and Jay C. Shambaugh (2010a), "Financial Exchange Rates and International Currency Exposures," American Economic Review 100(1), 518-540.

Lane, Philip R. and Jay C. Shambaugh (2010ab), "The Long or Short of It: Determinants of Foreign Currency Exposure in External Balance Sheets," Journal of International Economics 80(1), 33-44.

Milesi-Ferretti, Gian Maria (2009), "A \$2 Trillion Question," VOXEU (28 January 2009). 
Milesi-Ferretti, Gian Maria and Cédric Tille (2011), "The Great Retrenchment: International Capital Flows during the Global Financial Crisis," Economic Policy 26(66), 285-342.

Milesi-Ferretti, Gian Maria, Francesco Strobbe and Natalia Tamirisa (2010), "Bilateral Financial Linkages: A View on the Eve of the Financial Crisis," IMF Working Paper No. $10 / 257$.

Obstfeld, Maurice (2012a), "Financial Flows, Financial Crises, and Global Imbalances," Journal of International Money and Finance 31, 469-480.

Obstfeld, Maurice (2012b), "Does the Current Account Still Matter?," American Economic Review 102(3), 1-23.

Obstfeld, Maurice (2013), "On Keeping Your Powder Dry: Fiscal Foundations of Financial and Price Stability," mimeo, University of California at Berkeley.

Rose, Andrew R. (2014), "Surprising Similarities: Recent Monetary Regimes of Small Economies," Journal of International Money and Finance, forthcoming.

Tille, Cedric (2003), "The Impact of Exchange Rate Movements on U.S. Foreign Debt," Current Issues in Economics and Finance 9(1), Federal Reserve Bank of New York. 
Table 1: Aggregate foreign currency exposure

\begin{tabular}{|l|c|cc|cc|}
\hline \multirow{3}{*}{ Group } & Year & \multicolumn{2}{|c|}{$F X$ AGG } & \multicolumn{2}{c|}{ NETFX } \\
& & Mean & Median & Mean & Median \\
& & & & & \\
\hline \multirow{3}{*}{ ALL } & 1996 & -0.20 & -0.18 & -0.18 & -0.16 \\
& 2002 & -0.11 & -0.08 & -0.05 & -0.12 \\
& 2007 & 0.08 & 0.06 & 0.31 & 0.11 \\
& & & & & \\
\hline \multirow{3}{*}{ ADV } & 1996 & 0.06 & 0.07 & 0.24 & 0.08 \\
& 2002 & 0.07 & 0.05 & 0.36 & 0.17 \\
& 2007 & 0.12 & 0.08 & 0.70 & 0.35 \\
& & & & & \\
\hline \multirow{3}{*}{ EMDEV } & 1996 & -0.27 & -0.30 & -0.29 & -0.22 \\
& 2002 & -0.15 & -0.18 & -0.14 & -0.18 \\
& 2007 & 0.07 & 0.05 & 0.22 & 0.05 \\
& & & & & \\
\hline
\end{tabular}

Note: $F X A G G_{i t}=\omega_{i t}^{A} s_{i t}^{A}-\omega_{i t}^{L} s_{i t}^{L}$ where $\omega_{i t}^{A}$ is the share of foreign assets denominated in foreign currencies, $s_{i t}^{A}$ is the share of foreign assets in the sum of foreign assets and foreign liabilities and $\omega_{i t}^{L}, s_{i t}^{L}$ are defined analogously. NETFX $X_{i t}=F X A G G_{i t} * I F I_{i t}$ where IFI is the sum of foreign assets plus liabilities scaled by GDP. 
Table 2: Determinants of FXAGG

\begin{tabular}{|c|c|c|c|c|}
\hline & (1) & (2) & (3) & (4) \\
\hline Trade & $\begin{array}{c}0.10^{* * *} \\
(0.02)\end{array}$ & $\begin{array}{c}0.06^{* * *} \\
(0.02)\end{array}$ & $\begin{array}{c}0.02 \\
(0.02)\end{array}$ & $\begin{array}{c}0.02 \\
(0.02)\end{array}$ \\
\hline Size & $\begin{array}{c}0.03^{* * *} \\
(0.01)\end{array}$ & $\begin{array}{c}0.05^{* * * *} \\
(0.01)\end{array}$ & $\begin{array}{c}0.04^{* * *} \\
(0.01)\end{array}$ & $\begin{array}{c}0.04^{* * *} * \\
(0.01)\end{array}$ \\
\hline $\operatorname{Vol}(\mathrm{GDP})$ & $\begin{array}{c}0.15 \\
(0.43)\end{array}$ & $\begin{array}{c}1.72^{* * * *} \\
(0.45)\end{array}$ & $\begin{array}{c}1.05^{* * *} \\
(0.31)\end{array}$ & $\begin{array}{l}0.88^{* *} \\
(0.37)\end{array}$ \\
\hline $\operatorname{Vol}(\pi)$ & $\begin{array}{c}0.23 \\
(0.15)\end{array}$ & $\begin{array}{c}0.33^{* *} \\
(0.15)\end{array}$ & $\begin{array}{c}0.33^{* * *} \\
(0.12)\end{array}$ & $\begin{array}{c}0.33^{* * *} \\
(0.12)\end{array}$ \\
\hline $\operatorname{Vol}(\mathrm{E})$ & $\begin{array}{c}-1.32^{* * *} \\
(0.37)\end{array}$ & $\begin{array}{l}-0.46 \\
(0.37)\end{array}$ & $\begin{array}{l}-0.23 \\
(0.30)\end{array}$ & $\begin{array}{l}-0.28 \\
(0.29)\end{array}$ \\
\hline $\operatorname{Cov}(\mathrm{GDP}, \mathrm{E})$ & $\begin{array}{c}2.55^{* *} \\
(1.12)\end{array}$ & $\begin{array}{c}0.40 \\
(1.21)\end{array}$ & $\begin{array}{l}-0.85 \\
(0.89)\end{array}$ & $\begin{array}{l}-0.85 \\
(0.84)\end{array}$ \\
\hline Institutions & & $\begin{array}{c}0.13^{* * *} \\
(0.02)\end{array}$ & & $\begin{array}{l}-0.01 \\
(0.02)\end{array}$ \\
\hline Capital controls & & $\begin{array}{c}0.02^{* *} \\
(0.01)\end{array}$ & & $\begin{array}{l}0.002 \\
(0.01)\end{array}$ \\
\hline Peg & & $\begin{array}{c}0.03 \\
(0.02)\end{array}$ & & $\begin{array}{l}0.03^{*} \\
(0.02)\end{array}$ \\
\hline EMU & & $\begin{array}{c}-0.17^{* * *} \\
(0.03)\end{array}$ & & $\begin{array}{c}-0.18^{* * *} \\
(0.03)\end{array}$ \\
\hline$G D P^{P C}$ & & & $\begin{array}{c}0.13^{* * *} \\
(0.01)\end{array}$ & $\begin{array}{c}0.15^{* * *} \\
(0.01)\end{array}$ \\
\hline Year 1996 & $\begin{array}{c}-0.31^{* * *} \\
(0.05)\end{array}$ & $\begin{array}{c}-0.46^{* * *} \\
(0.05)\end{array}$ & $\begin{array}{c}-1.47^{* * *} \\
(0.08)\end{array}$ & $\begin{array}{c}-1.61^{* * *} \\
(0.11)\end{array}$ \\
\hline Year 2000 & $\begin{array}{c}0.03 \\
(0.04)\end{array}$ & $\begin{array}{c}0.04 \\
(0.03)\end{array}$ & $\begin{array}{c}0.02 \\
(0.03)\end{array}$ & $\begin{array}{c}0.03 \\
(0.03)\end{array}$ \\
\hline Year 2004 & $\begin{array}{c}0.11^{* * *} \\
(0.04)\end{array}$ & $\begin{array}{c}0.14^{* * * *} \\
(0.03)\end{array}$ & $\begin{array}{c}0.09^{* * *} \\
(0.03)\end{array}$ & $\begin{array}{c}0.10^{* * * *} \\
(0.03)\end{array}$ \\
\hline Year 2007 & $\begin{array}{c}0.24^{* * *} \\
(0.04)\end{array}$ & $\begin{array}{c}0.28^{* * *} \\
(0.03)\end{array}$ & $\begin{array}{c}0.20^{* * *} \\
(0.03)\end{array}$ & $\begin{array}{c}0.21^{* * *} \\
(0.03)\end{array}$ \\
\hline Year 2012 & $\begin{array}{c}0.22^{* * *} \\
(0.04)\end{array}$ & $\begin{array}{c}0.28^{* * * *} \\
(0.04)\end{array}$ & $\begin{array}{c}0.17^{* * *} \\
(0.03)\end{array}$ & $\begin{array}{c}0.18^{* * *} \\
(0.03)\end{array}$ \\
\hline $\begin{array}{l}\text { Observations } \\
R^{2}\end{array}$ & $\begin{array}{c}571 \\
0.22\end{array}$ & $\begin{array}{l}571 \\
0.35\end{array}$ & $\begin{array}{c}571 \\
0.46\end{array}$ & $\begin{array}{l}571 \\
0.48\end{array}$ \\
\hline
\end{tabular}

Note: Pooled regressions based on data for 1996, 2000, 2004, 2007 and 2012. Robust standard errors are in parentheses. Statistical significance is as follows ${ }^{* * *} \mathrm{p}<0.01,{ }^{* *} \mathrm{p}<0.05,{ }^{*} \mathrm{p}<0.1$. Trade refers to trade openness ratio to GDP. Size is the logarithm of population. Vol(GDP) is the standard deviation of year-on-year GDP growth. $\operatorname{Vol}(\pi)$ is the standard deviation of monthon-month CPI inflation. $\mathrm{Vol}(\mathrm{E})$ is the standard deviation of month-on-month nominal foreign exchange rate change. $\operatorname{Cov}(\mathrm{GDP}, \mathrm{E})$ is the covariance between GDP growth and NEER change. All measures of volatilities and covariance are3œmputed using a 15-year window. Institutions refers to World Bank Governance Indicators estimates; Capital controls are the Chinn-Ito's Capital Account Openness Index; Peg is a dummy variable that takes value 1 for countries with either peg or soft pegs as defined by Shambaugh (2004); EMU is a dummy variable for EMU member countries; $G D P^{P C}$ is GDP per capita in log levels. Finally, Year 1996, 2000, 2004, 2007 and 2012 are dummy variables. 
Table 3: Distribution of VALXR

\begin{tabular}{|c|cc|cccc|}
\hline Year & Mean & Median & $10^{\text {th }}$ & $25^{\text {th }}$ & $75^{\text {th }}$ & $90^{\text {th }}$ \\
\hline & & & & & & \\
2002 & -1.6 & -0.1 & -10.6 & -2.8 & 2.0 & 6.9 \\
2003 & 0.4 & 0.3 & -4.8 & -1.5 & 2.8 & 6.5 \\
2004 & 0.1 & 0.5 & -3.1 & -0.6 & 1.5 & 3.9 \\
2005 & -0.7 & -0.4 & -5.7 & -2.2 & 1.1 & 5.0 \\
2006 & 0.9 & 0.7 & -2.6 & -0.5 & 2.2 & 4.3 \\
2007 & 0.5 & 0.2 & -2.0 & -0.7 & 1.2 & 3.3 \\
2008 & -1.8 & -1.7 & -6.8 & -4.0 & -0.2 & 2.4 \\
2009 & 0.2 & 0.4 & -3.2 & -0.2 & 1.4 & 3.1 \\
2010 & -0.5 & -0.8 & -4.5 & -2.2 & 0.5 & 1.9 \\
2011 & -0.5 & -0.3 & -2.5 & -1.2 & 0.2 & 1.8 \\
2012 & -0.4 & 0.2 & -2.0 & -0.5 & 0.7 & 1.8 \\
& & & & & & \\
\hline
\end{tabular}

Note: Table shows the size of VALXR as a percentage of GDP. $10^{\text {th }}, 25^{\text {th }}, 75^{\text {th }}$ and $90^{\text {th }}$ refer to the $10^{t h}, 25^{t h}, 75^{\text {th }}$ and $90^{\text {th }}$ percentiles of observations within each year. 
Table 4: VALXR 2008 in US Dollars. Largest Winners and Losers.

\begin{tabular}{|lr|lr|}
\hline \multicolumn{2}{|c|}{ Gains } & \multicolumn{2}{c|}{ Losses } \\
\hline & & \multicolumn{2}{c|}{} \\
United Kingdom & 945.8 & Japan & 936.5 \\
Canada & 221.9 & United States & 772.5 \\
Norway & 87.0 & Switzerland & 250.9 \\
Korea & 54.9 & China & 221.7 \\
Sweden & 50.9 & Singapore & 185.9 \\
& & & \\
\hline
\end{tabular}

Note: Top five countries exhibiting the largest values of VALXR in 2008 in absolute size. Units are billions of US dollars. 
Table 5: Valuation Effects, Currency Exposures and Exchange Rate Movements: 2008

\begin{tabular}{|l|c|c|c|c|c|}
\hline & \multicolumn{2}{|c|}{ Valuation Gains (27) } & \multicolumn{2}{|c|}{ Valuation Losses (90) } & \\
\hline & $F X A G G>0$ & $F X A G G<0$ & $F X A G G>0$ & $F X A G G<0$ & Total \\
\hline $\begin{array}{l}I N D^{A} \text { and } I N D^{L} \\
\text { appreciate }\end{array}$ & 1 & 3 & 13 & 3 & 20 \\
\hline $\begin{array}{l}I N D^{A} \text { and } I N D^{L} \\
\text { depreciate }\end{array}$ & 22 & 1 & 15 & 28 & 66 \\
\hline $\begin{array}{l}I N D^{A} \text { appreciates } \\
I N D^{L} \text { depreciates }\end{array}$ & 23 & 4 & 24 & 7 & 31 \\
\hline \begin{tabular}{l} 
Total \\
\hline
\end{tabular} & & 52 & & 38 & \\
\hline
\end{tabular}

Note: Based on a sample of 117 advanced, emerging market economies and developing countries. End-2007 values of $F X A G G_{i t}=\omega_{i t}^{A} s_{i t}^{A}-\omega_{i t}^{L} s_{i t}^{L}$ where $\omega_{i t}^{A}$ is the share of foreign assets denominated in foreign currencies, $s_{i t}^{A}$ is the share of foreign assets in the sum of foreign assets and foreign liabilities and $\omega_{i t}^{L}, s_{i t}^{L}$ are defined analogously. $I N D^{A}$ and $I N D^{L}$ refer movements in asset- and liability-weighted exchange rate indices during 2008. 
Table 6: Counterfactual VALXR for 2008

\begin{tabular}{|c|cc|cccc|}
\hline VALXR & Mean & Median & $10^{\text {th }}$ & $25^{\text {th }}$ & $75^{\text {th }}$ & $90^{\text {th }}$ \\
& & & & & & \\
\hline Curr. Exp (2007), IFI (2007) & -1.8 & -1.7 & -6.8 & -4.0 & -0.2 & 2.4 \\
& & & & & & \\
Curr. Exp (2002), IFI (2002) & -4.9 & -2.8 & -12.1 & -6.3 & -1.1 & 1.2 \\
Curr. Exp (1996), IFI (1996) & -4.3 & -2.6 & -12.1 & -6.1 & -1.0 & 0.0 \\
& & & & & & \\
Curr. Exp (2002), IFI (2007) & -7.2 & -2.7 & -11.3 & -6.1 & -1.1 & 0.9 \\
Curr. Exp (1996), IFI (2007) & -7.5 & -3.4 & -15.2 & -7.6 & -1.2 & 0.0 \\
& & & & & & \\
\hline
\end{tabular}

Note: Table shows the size of VALXR as a percentage of GDP. To compute the counter factual we use the currency exposures in 2002 and 1996. In addition, we also look at the contribution of IFI by fixing this at 2007 levels but allowing currency exposures to be those in 2002 and 1996. In all cases, we take the changes in bilateral exchange rates from 2007 to 2008 . $10^{t h}, 25^{t h}, 75^{t h}$ and $90^{t h}$ refer to the $10^{t h}, 25^{t h}, 75^{t h}$ and $90^{t h}$ percentiles of observations within each counter factual. 
Table 7: VALXR 2008: Regression Models by Country Group

\begin{tabular}{|c|c|c|c|c|c|c|c|c|}
\hline & (1) & $\begin{array}{l}\text { ALL } \\
(2)\end{array}$ & $(3)$ & \multicolumn{2}{|c|}{$\mathrm{ADV}$} & \multicolumn{2}{|c|}{ EMDEV } & (8) \\
\hline NFA/GDP (07) & $\begin{array}{l}-0.08 \\
(0.07)\end{array}$ & $\begin{array}{l}-0.09 \\
(0.08)\end{array}$ & $\begin{array}{l}-0.11 \\
(0.10)\end{array}$ & $\begin{array}{c}-0.28^{* *} \\
(0.12)\end{array}$ & $\begin{array}{c}-0.26^{*} \\
(0.12)\end{array}$ & $\begin{array}{l}-0.05 \\
(0.08)\end{array}$ & $\begin{array}{l}-0.07 \\
(0.09)\end{array}$ & -0.05 \\
\hline $\mathrm{CA} / \mathrm{GDP}(07)$ & $\begin{array}{c}0.22 \\
(0.19)\end{array}$ & $\begin{array}{c}0.08 \\
(0.21)\end{array}$ & $\begin{array}{l}-0.14 \\
(0.51)\end{array}$ & $\begin{array}{l}1.46^{*} \\
(0.70)\end{array}$ & $\begin{array}{c}1.56^{* *} \\
(0.69)\end{array}$ & $\begin{array}{c}0.13 \\
(0.18)\end{array}$ & $\begin{array}{l}-0.09 \\
(0.20)\end{array}$ & $\begin{array}{l}-1.00 \\
(0.77)\end{array}$ \\
\hline GDP Growth & & $\begin{array}{l}-0.16 \\
(0.32)\end{array}$ & $\begin{array}{l}-0.05 \\
(0.57)\end{array}$ & & $\begin{array}{l}-3.64 \\
(2.52)\end{array}$ & & $\begin{array}{c}0.30 \\
(0.52)\end{array}$ & $\begin{array}{c}1.22 \\
(1.00)\end{array}$ \\
\hline STKRET & & $\begin{array}{c}0.10^{* *} \\
(0.04)\end{array}$ & $\begin{array}{c}0.15^{* *} \\
(0.07)\end{array}$ & & $\begin{array}{l}0.39^{*} \\
(0.22)\end{array}$ & & $\begin{array}{c}0.08 \\
(0.05)\end{array}$ & $\begin{array}{c}0.10 \\
(0.08)\end{array}$ \\
\hline DLRATE & & $\begin{array}{l}-0.23 \\
(0.41)\end{array}$ & $\begin{array}{l}-0.82 \\
(0.81)\end{array}$ & & $\begin{array}{l}-0.47 \\
(3.61)\end{array}$ & & $\begin{array}{c}-0.12 \\
(0.33)\end{array}$ & $\begin{array}{l}-1.83 \\
(1.27)\end{array}$ \\
\hline Constant & $\begin{array}{l}-3.16 \\
(2.64)\end{array}$ & $\begin{array}{l}-1.11 \\
(3.59)\end{array}$ & $\begin{array}{c}0.15 \\
(5.81)\end{array}$ & $\begin{array}{l}-5.53 \\
(3.56)\end{array}$ & $\begin{array}{c}11.09 \\
(11.69)\end{array}$ & $\begin{array}{l}-2.79 \\
(3.24)\end{array}$ & $\begin{array}{l}-3.84 \\
(4.86)\end{array}$ & $\begin{array}{l}-6.52 \\
(7.31)\end{array}$ \\
\hline $\begin{array}{l}\text { Obs. } \\
R^{2}\end{array}$ & $\begin{array}{l}117 \\
0.04\end{array}$ & $\begin{array}{c}81 \\
0.16\end{array}$ & $\begin{array}{c}58 \\
0.26\end{array}$ & $\begin{array}{c}22 \\
0.31\end{array}$ & $\begin{array}{c}22 \\
0.52\end{array}$ & $\begin{array}{c}95 \\
0.02\end{array}$ & $\begin{array}{c}59 \\
0.15\end{array}$ & $\begin{array}{c}36 \\
0.39\end{array}$ \\
\hline
\end{tabular}

Note: Robust standard errors in parentheses. Statistical significance is as follows *** $\mathrm{p}<0.01,{ }^{* *} \mathrm{p}<0.05,{ }^{*} \mathrm{p}<0.1$. NFA/GDP $(07)$ is the 2007 outstanding net foreign asset position scaled by GDP. CA/GDP (07) is the current account to GDP ratio in 2007. GDP Growth is real GDP growth in 2008. STKRET is stock market return in 2008. $\triangle$ LRATE is the difference in the long-term interest rate between 2007 and 2008. Columns (3) and (8) are estimated using the high-quality sample. 
Table 8: VALXR 2008: Regression Models by Exchange Rate Regime

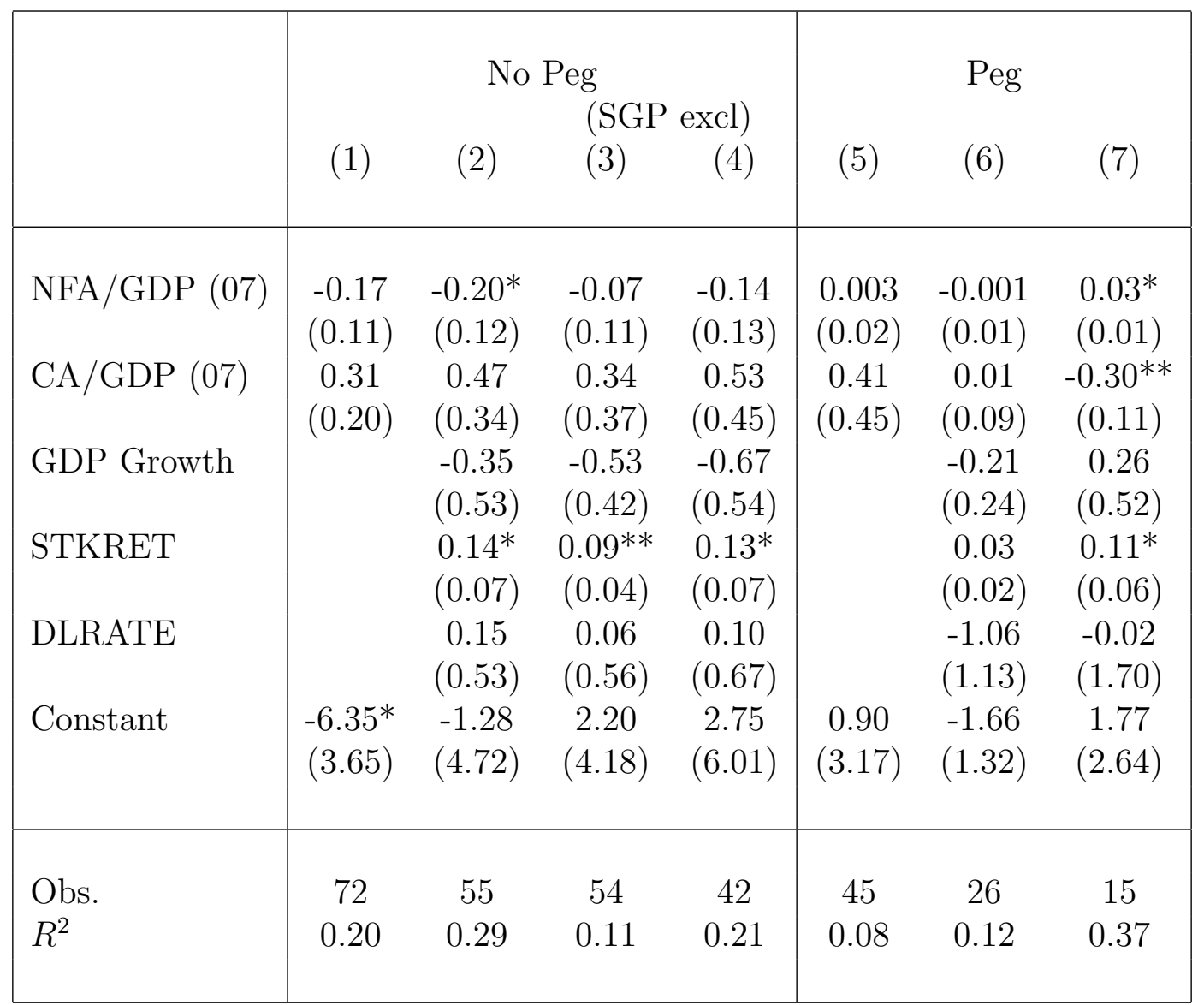

Note: Robust standard errors in parentheses. Statistical significance is as follows *** $\mathrm{p}<0.01,{ }^{* *} \mathrm{p}<0.05,{ }^{*} \mathrm{p}<0.1$. Peg sample is formed by countries with either peg or soft pegs in 2008 as defined by Shambaugh (2004). NFA/GDP (07) is the 2007 outstanding net foreign asset position scaled by GDP. CA/GDP (07) is the current account to GDP ratio in 2007. GDP Growth is real GDP growth in 2008. STKRET is stock market return in 2008. $\triangle$ LRATE is the difference in the long-term interest rate between 2007 and 2008. Column (3) excludes Singapore from the regression model as this country exhibited a very large VALX value in 2008. Columns (4) and (7) are estimated using the high-quality sample. 
Table 9: VALXR (2008-2012): Regression Models by Country Group

\begin{tabular}{|c|c|c|c|c|c|c|c|c|}
\hline & \multicolumn{2}{|r|}{$\begin{array}{l}\text { ALL } \\
(2)\end{array}$} & (3) & \multicolumn{2}{|c|}{$\mathrm{ADV}$} & \multicolumn{3}{|c|}{ EMDEV } \\
\hline NFA/GDP (07) & $\begin{array}{l}-0.06 \\
(0.16)\end{array}$ & $\begin{array}{l}-0.11 \\
(0.20)\end{array}$ & $\begin{array}{l}-0.08 \\
(0.27)\end{array}$ & $\begin{array}{l}-0.41^{*} \\
(0.23)\end{array}$ & $\begin{array}{l}-0.38 \\
(0.26)\end{array}$ & $\begin{array}{l}0.001 \\
(0.18)\end{array}$ & $\begin{array}{l}-0.04 \\
(0.24)\end{array}$ & $\begin{array}{c}0.04 \\
(0.31)\end{array}$ \\
\hline CA/GDP (07) & $\begin{array}{c}0.23 \\
(0.36)\end{array}$ & $\begin{array}{c}0.23 \\
(0.63)\end{array}$ & $\begin{array}{l}-0.80 \\
(1.23)\end{array}$ & $\begin{array}{c}1.56 \\
(1.13)\end{array}$ & $\begin{array}{c}1.17 \\
(1.19)\end{array}$ & $\begin{array}{c}0.12 \\
(0.33)\end{array}$ & $\begin{array}{c}0.06 \\
(0.65)\end{array}$ & $\begin{array}{l}-1.71 \\
(1.69)\end{array}$ \\
\hline DGDPg_0812-07 & & $\begin{array}{l}-1.19 \\
(1.12)\end{array}$ & $\begin{array}{c}0.44 \\
(1.88)\end{array}$ & & $\begin{array}{c}0.50 \\
(3.30)\end{array}$ & & $\begin{array}{l}-1.03 \\
(1.16)\end{array}$ & $\begin{array}{l}1.70 \\
(2.83)\end{array}$ \\
\hline STKRET_0812 & & $\begin{array}{c}0.33 \\
(0.34)\end{array}$ & $\begin{array}{l}-0.34 \\
(0.38)\end{array}$ & & $\begin{array}{l}1.18 \\
(0.77)\end{array}$ & & $\begin{array}{c}0.32 \\
(0.39)\end{array}$ & $\begin{array}{l}-0.68 \\
(0.43)\end{array}$ \\
\hline DLRATE_0812-07 & & $\begin{array}{l}-0.10 \\
(1.70)\end{array}$ & $\begin{array}{l}-3.13 \\
(2.83)\end{array}$ & & $\begin{array}{c}3.56 \\
(3.29)\end{array}$ & & $\begin{array}{l}-0.29 \\
(1.98)\end{array}$ & $\begin{array}{l}-4.40 \\
(3.41)\end{array}$ \\
\hline Constant & $\begin{array}{l}-4.42 \\
(5.16)\end{array}$ & $\begin{array}{c}-10.98^{*} \\
(6.46)\end{array}$ & $\begin{array}{l}-7.67 \\
(9.75)\end{array}$ & $\begin{array}{l}-9.00 \\
(6.20)\end{array}$ & $\begin{array}{l}-2.18 \\
(8.95)\end{array}$ & $\begin{array}{l}-3.28 \\
(6.21)\end{array}$ & $\begin{array}{r}-10.29 \\
(9.24)\end{array}$ & $\begin{array}{c}-1.16 \\
(16.14)\end{array}$ \\
\hline $\begin{array}{l}\text { Obs. } \\
R^{2}\end{array}$ & $\begin{array}{l}117 \\
0.01\end{array}$ & $\begin{array}{c}81 \\
0.05\end{array}$ & $\begin{array}{c}58 \\
0.12\end{array}$ & $\begin{array}{c}22 \\
0.41\end{array}$ & $\begin{array}{c}22 \\
0.47\end{array}$ & $\begin{array}{c}95 \\
0.002\end{array}$ & $\begin{array}{c}59 \\
0.02\end{array}$ & $\begin{array}{c}36 \\
0.14\end{array}$ \\
\hline
\end{tabular}

Note: Robust standard errors in parentheses. Statistical significance is as follows *** $\mathrm{p}<0.01,{ }^{* *} \mathrm{p}<0.05,{ }^{*} \mathrm{p}<0.1$. NFA/GDP $(07)$ is the 2007 outstanding net foreign asset position scaled by GDP. CA/GDP (07) is the current account to GDP ratio in 2007. $\triangle$ GDPg_0812-07 is the difference between the average of the year-on-year real GDP growth in the period 2008-2012 and real GDP growth in 2007. STKRET_0812 is the average stock market return in 2008-2012. $\triangle$ LRATE_0812-07 is the difference between the average longterm interest rate in 2008-2012 and its value in 2007. In contrast to Tables 7 and 8, this table fixes GDP at 2007 values to construct VALXR. We do this to prevent the right hand side variables to affect the denominator of VALXR. Columns (3) and (8) are estimated using the high-quality sample. 
Table 10: VALXR (2008-2012): Regression Models by Exchange Rate Regime

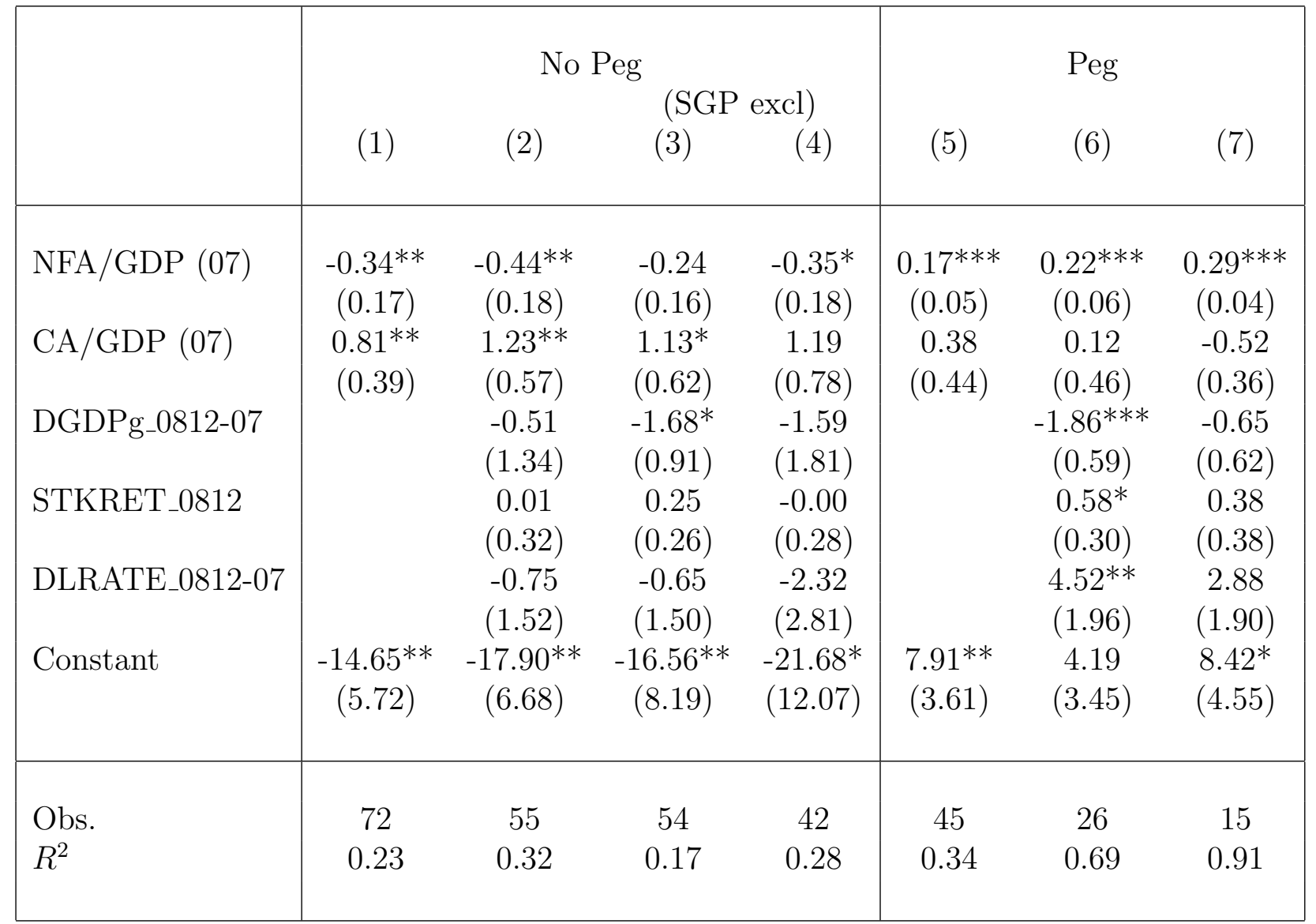

Note: Robust standard errors in parentheses. Statistical significance is as follows *** $\mathrm{p}<0.01,{ }^{*} \mathrm{p}<0.05,{ }^{*} \mathrm{p}<0.1$. Peg sample is formed by countries with either peg or soft pegs in 2008 as defined by Shambaugh (2004). NFA/GDP (07) is the 2007 outstanding net foreign asset position scaled by GDP. CA/GDP (07) is the current account to GDP ratio in 2007. $\triangle$ GDPg_0812-07 is the difference between the average of the year-on-year real GDP growth in the period 2008-2012 and real GDP growth in 2007. STKRET_0812 is the average stock market return in 2008-2012. $\Delta$ LRATE_0812-07 is the difference between the average long-term interest rate in 2008-2012 and its value in 2007. Column (3) excludes Singapore from the regression model as this country exhibited a very large VALX value. In contrast to Tables 7 and 8, this table fixes GDP at 2007 values to construct VALXR. We do this to prevent the right hand side variables to affect the denominator of VALXR. Columns (4) and (7) are estimated using the high-quality sample. 
Figure 1: FXAGG distributions

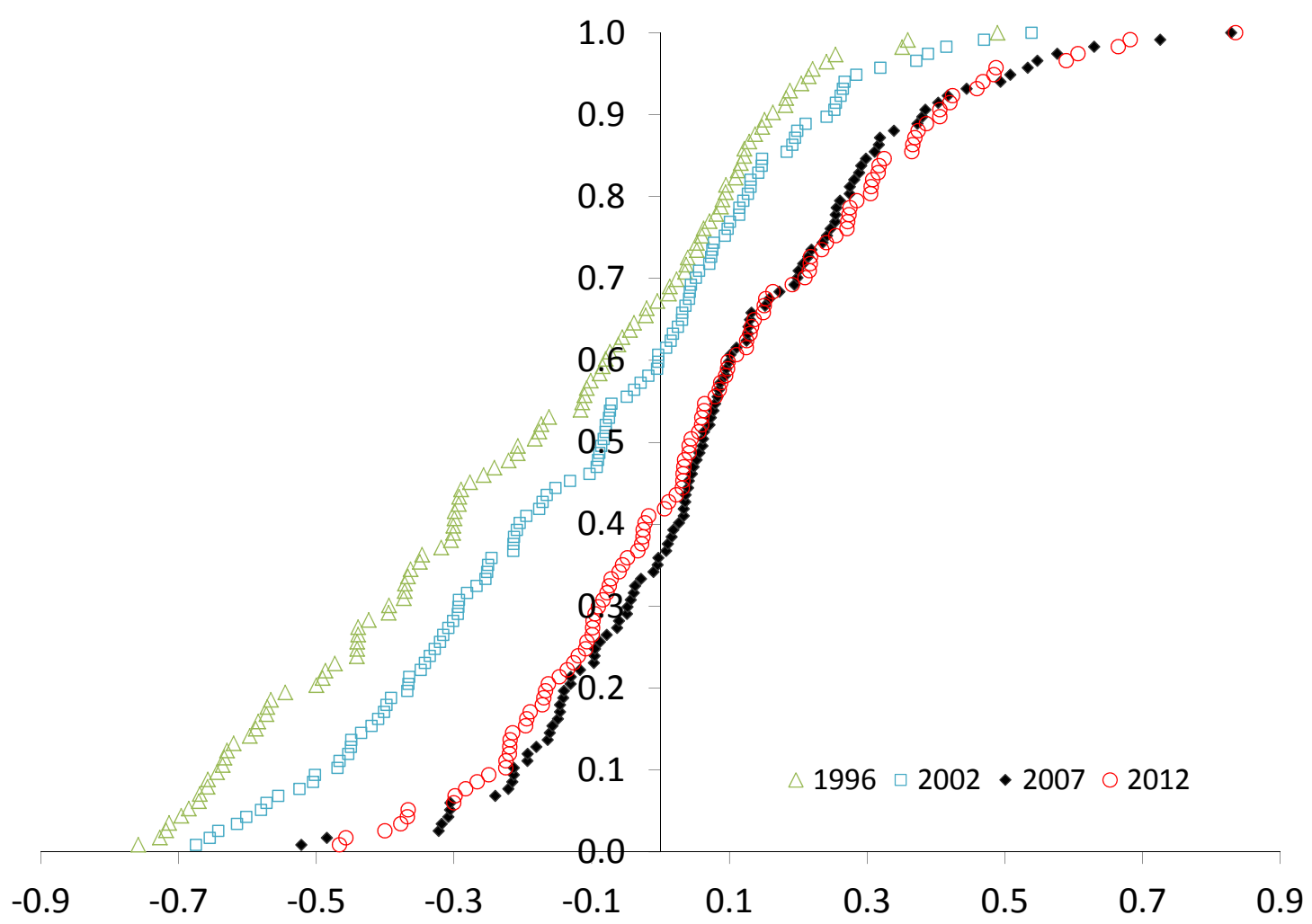

Note: FXAGG distributions for 1996, 2002, 2007 and 2012 based on a sample of 117 countries (22 advanced plus 95 emerging/developing). $F X A G G_{i t}=\omega_{i t}^{A} s_{i t}^{A}-\omega_{i t}^{L} s_{i t}^{L}$ where $\omega_{i t}^{A}$ is the share of foreign assets denominated in foreign currencies, $s_{i t}^{A}$ is the share of foreign assets in the sum of foreign assets and foreign liabilities and $\omega_{i t}^{L}, s_{i t}^{L}$ are defined analogously. 
Figure 2: International Financial Integration

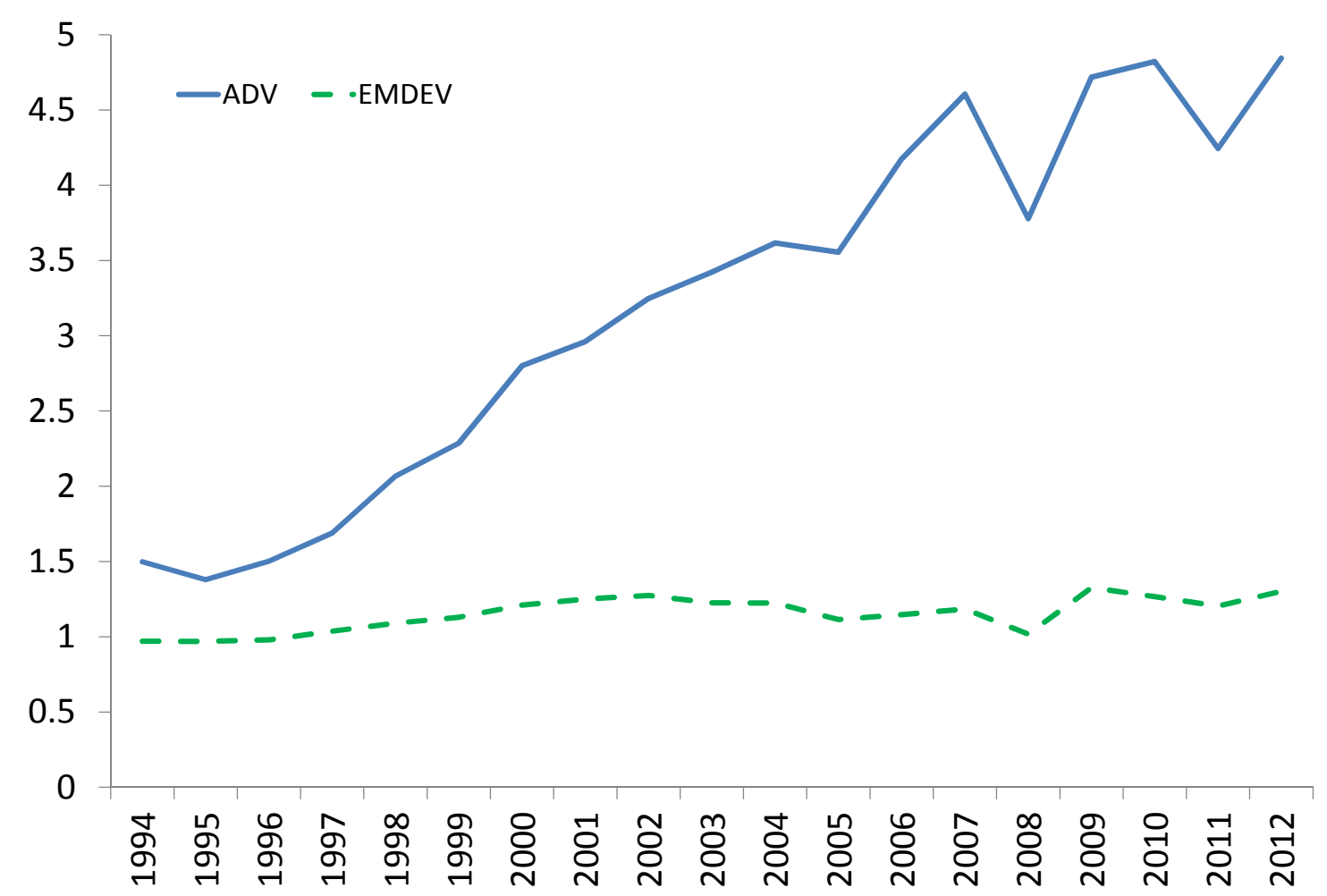

Note: This figure reports the median of the International Financial Integration (IFI) index for 22 advanced (ADV) countries and for 95 emerging/developing (EMDEV) economies. $I F I_{i t}=\left(A_{i t}+L_{i t}\right) / G D P_{i t}$ is defined as the sum of foreign assets $\left(A_{i t}\right)$ plus foreign liabilities $\left(L_{i t}\right)$ scaled by GDP. 
Figure 3: NETFX distribution

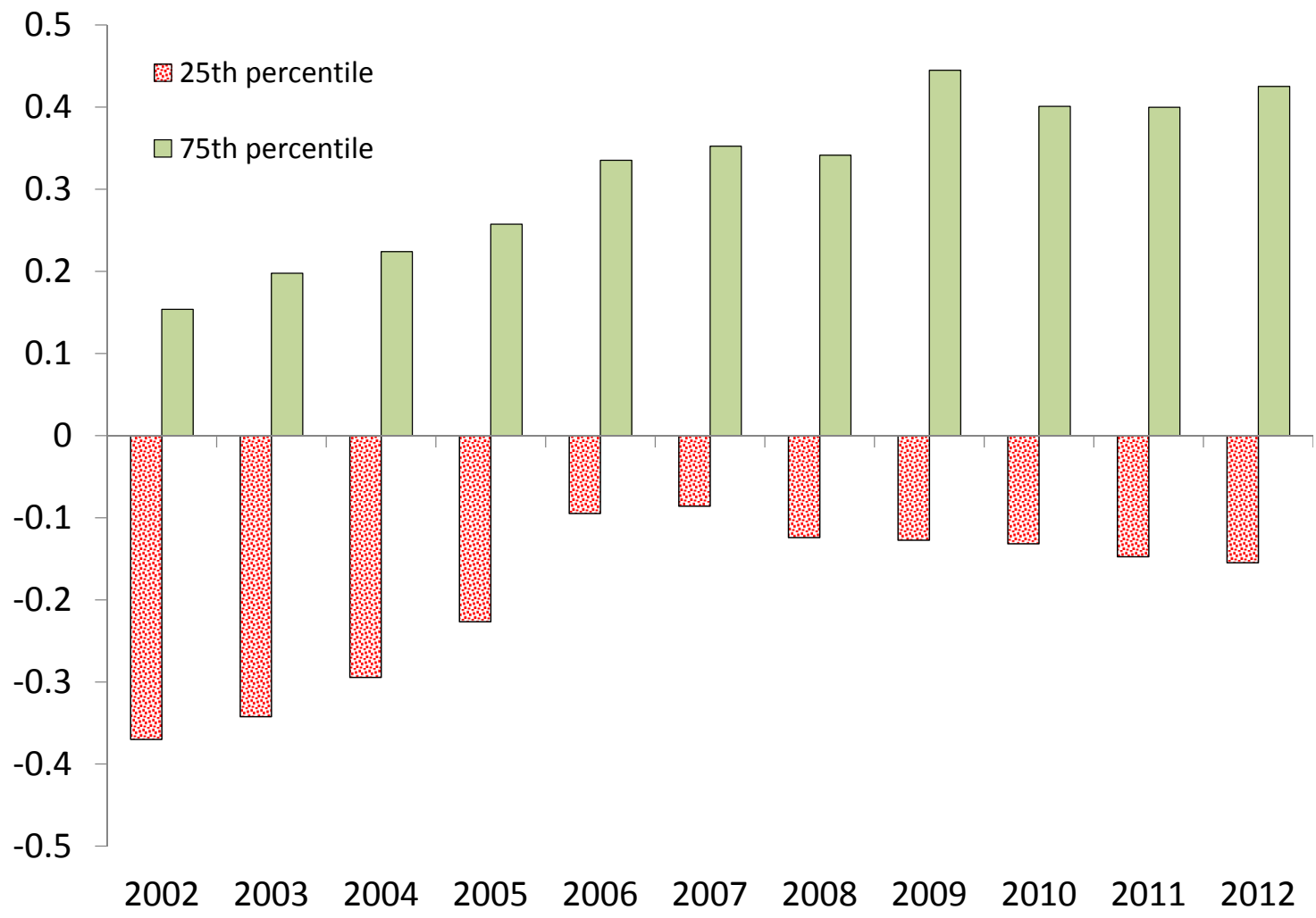

Note: This figure reports the $25^{\text {th }}$ and $75^{\text {th }}$ percentiles of the NETFX distribution based on a sample of 117 countries (22 advanced plus 95 emerging/developing). NETF $X_{i t}=$ $F X A G G_{i t} * I F I_{i t} . F X A G G_{i t}=\omega_{i t}^{A} s_{i t}^{A}-\omega_{i t}^{L} s_{i t}^{L}$ where $\omega_{i t}^{A}$ and $\omega_{i t}^{L}$ are the shares of foreign assets and liabilities denominated in foreign currencies. $s_{i t}^{A}=A_{i t} /\left(A_{i t}+L_{i t}\right)$ and $s_{i t}^{L}=$ $L_{i t} /\left(A_{i t}+L_{i t}\right)$ are the shares of foreign assets and foreign liabilities in total cross-border holdings. $I F I_{i t}=\left(A_{i t}+L_{i t}\right) / G D P_{i t}$ is the International Financial Indicator index defined as the sum of foreign assets $\left(A_{i t}\right)$ plus foreign liabilities $\left(L_{i t}\right)$ scaled by GDP. 
Figure 4: FXBILAT distributions for main global currencies in 2007

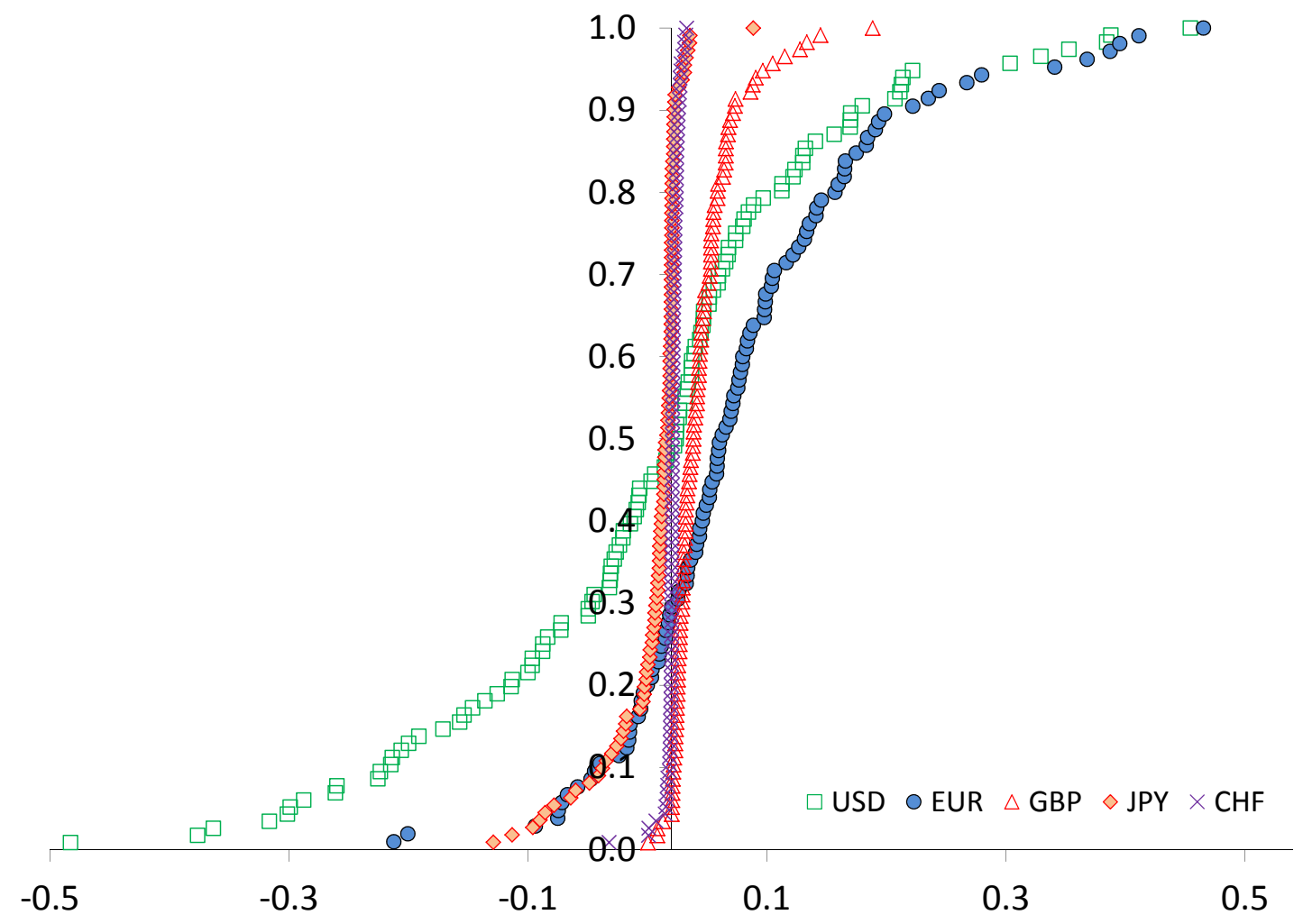

Note: FXBILAT distributions (or net financial currency weights) for the five major global currencies. These are US Dollar (USD), Euro (EUR), British Pound (GBP), Japanese Yen (JPY) and Swiss Franc (CHF). The distributions are based on a sample of 117 countries (22 advanced plus 95 emerging/developing). FXBILAT $=\omega_{i j t}^{F}$, where $\omega_{i j t}^{F}$ are the aggregate net financial weights defined as $\omega_{i j t}^{F}=\omega_{i j t}^{A} s_{i t}^{A}-\omega_{i j t}^{L} s_{i t}^{L} . \omega_{i j t}^{A}$ and $\omega_{i j t}^{L}$ are the weights for currency $j$ in period $t$ in country $i$ 's foreign assets and foreign liabilities. $s_{i t}^{A}=A_{i t} /\left(A_{i t}+L_{i t}\right)$ and $s_{i t}^{L}=L_{i t} /\left(A_{i t}+L_{i t}\right)$ are the shares of foreign assets and foreign liabilities in total cross-border holdings. 
Figure 5: FXBILAT distributions for main and other currencies in 2007

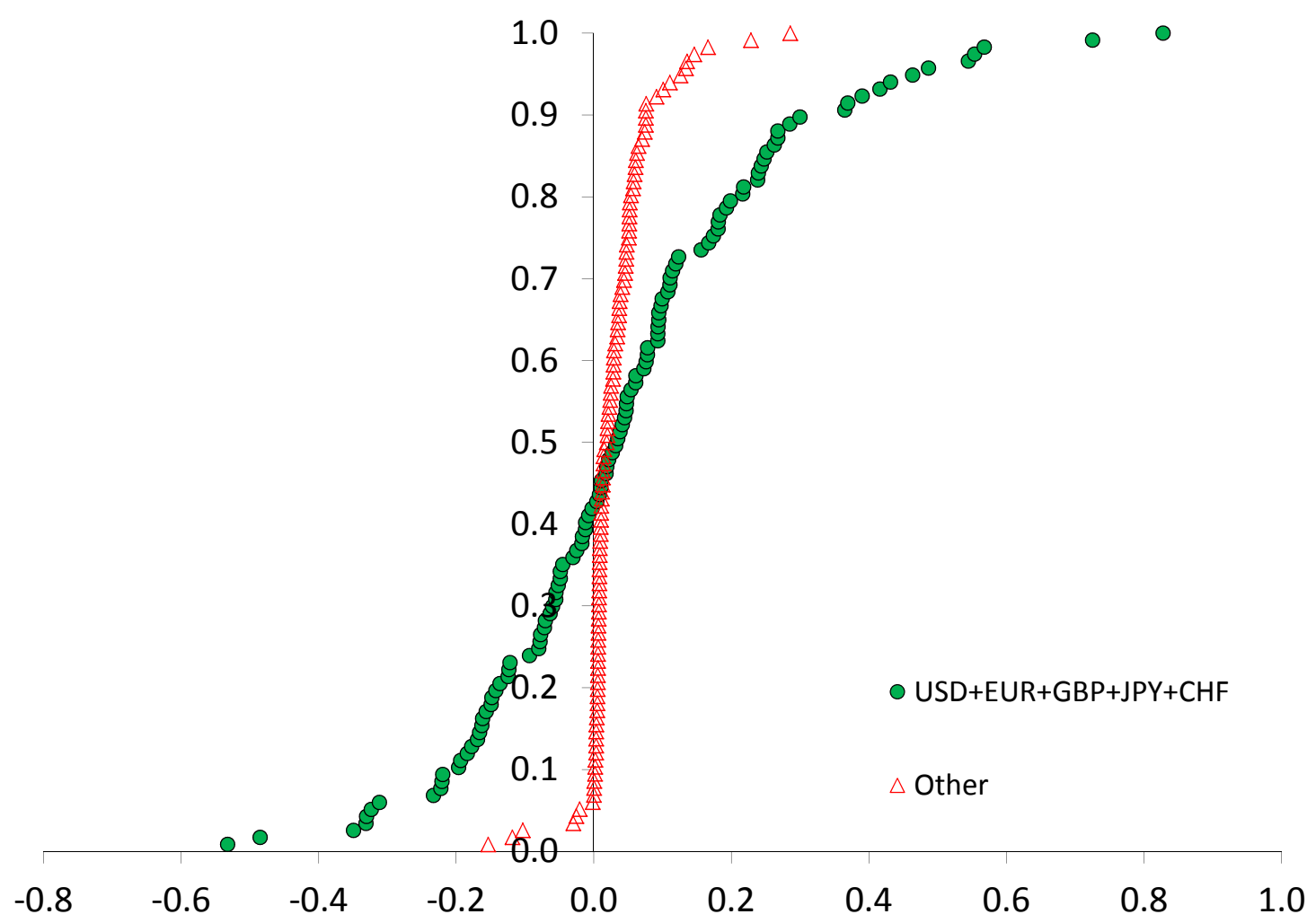

Note: FXBILAT distributions (or net financial currency weights) for the sum the five major global currencies and the sum of other currencies. These distributions are based on a sample of 117 countries (22 advanced plus 95 emerging/developing). The global currencies are US Dollar (USD), Euro (EUR), British Pound (GBP), Japanese Yen (JPY) and Swiss Franc (CHF). Other currencies are the currencies excluding the main five which are issued by the countries in the sample. FXBILAT $=\omega_{i j t}^{F}$, where $\omega_{i j t}^{F}$ are the aggregate net financial weights defined as $\omega_{i j t}^{F}=\omega_{i j t}^{A} s_{i t}^{A}-\omega_{i j t}^{L} s_{i t}^{L} . \omega_{i j t}^{A}$ and $\omega_{i j t}^{L}$ are the weights for currency $j$ in period $t$ in country $i$ 's foreign assets and foreign liabilities. $s_{i t}^{A}=A_{i t} /\left(A_{i t}+L_{i t}\right)$ and $s_{i t}^{L}=L_{i t} /\left(A_{i t}+L_{i t}\right)$ are the shares of foreign assets and foreign liabilities in total cross-border holdings. 
Figure 6: VALXR distribution

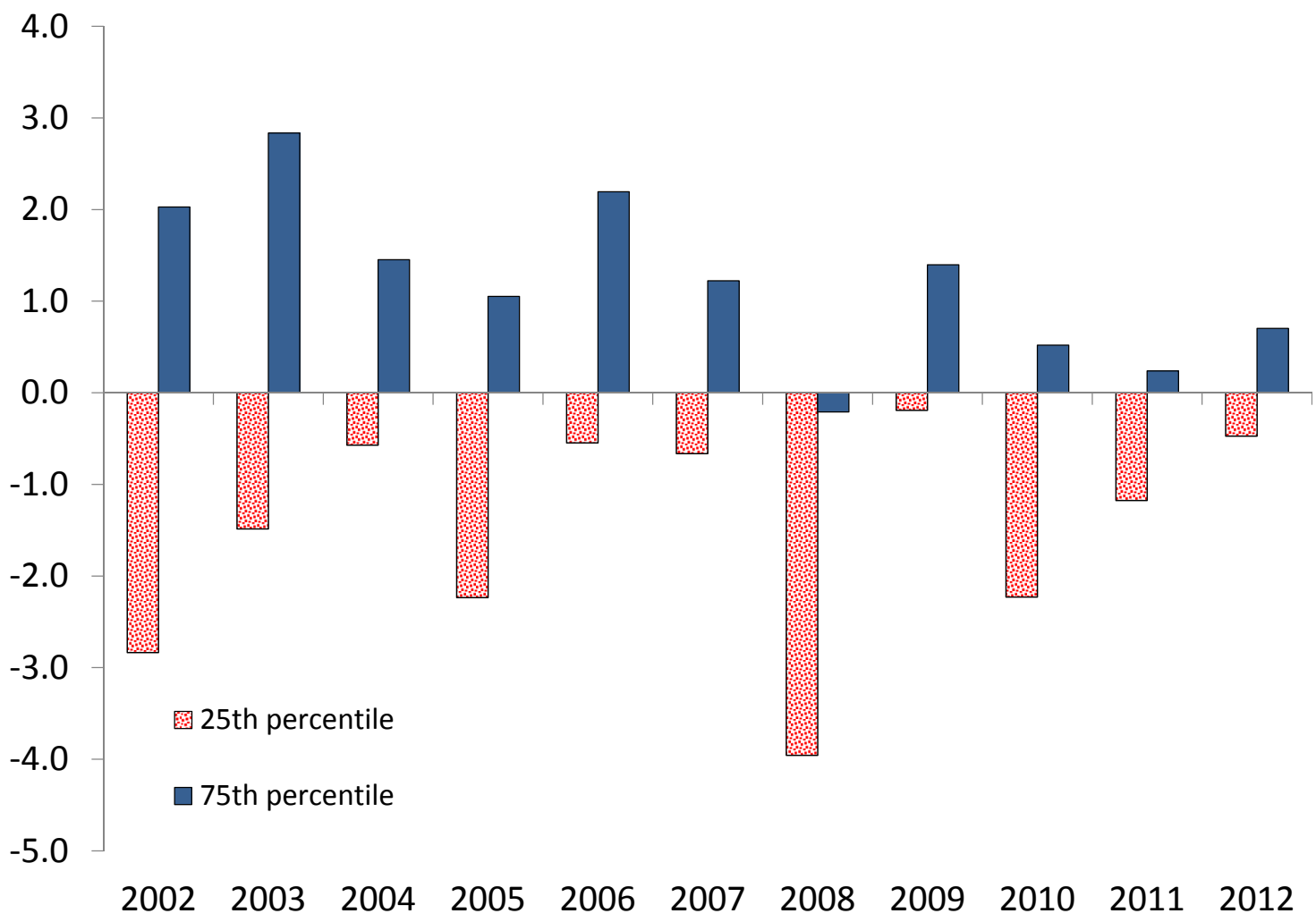

Note: This figure reports the $25^{t h}$ and $75^{\text {th }}$ percentiles of the $V A L X R$ distribution based on a sample of 117 countries (22 advanced plus 95 emerging/developing). $V A L X R$ are the exchange rate induced valuation effects scaled by GDP. This is defined by $V A L X R_{i t}=$ $\% \Delta I_{i t}^{F} * I F I_{i t-1}$, where $\% \Delta I_{i t}^{F}$ is the percentage change in the aggregate net financial exchange rate index and $I F I_{i t}=\left(A_{i t}+L_{i t}\right) / G D P_{i t}$ is the International Financial Indicator index defined at the sum of foreign assets $\left(A_{i t}\right)$ plus foreign liabilities $\left(L_{i t}\right)$ scaled by GDP. $I_{t}^{F}$ is defined as $I_{t}^{F}=I_{t-1}^{F}\left(1+\sum \omega_{i j t-1}^{F} * \% \Delta E_{i j t}\right)$, where $\omega_{i j t-1}^{F}$ are the previous period net currency weights and $\% \Delta E_{i j t}$ is the percentage change in the bilateral nominal exchange rate. $\omega_{i j t}^{F}$ are the aggregate net financial weights defined as $\omega_{i j t}^{F}=\omega_{i j t}^{A} s_{i t}^{A}-\omega_{i j t}^{L} s_{i t}^{L} . \omega_{i j t}^{A}$ and $\omega_{i j t}^{L}$ are the weights for currency $j$ in period $t$ in country $i$ 's foreign assets and foreign liabilities. $s_{i t}^{A}=A_{i t} /\left(A_{i t}+L_{i t}\right)$ and $s_{i t}^{L}=L_{i t} /\left(A_{i t}+L_{i t}\right)$ are the shares of foreign assets and foreign liabilities in total cross-border holdings. 
Figure 7: VALXR 2008 and VALXR 2009

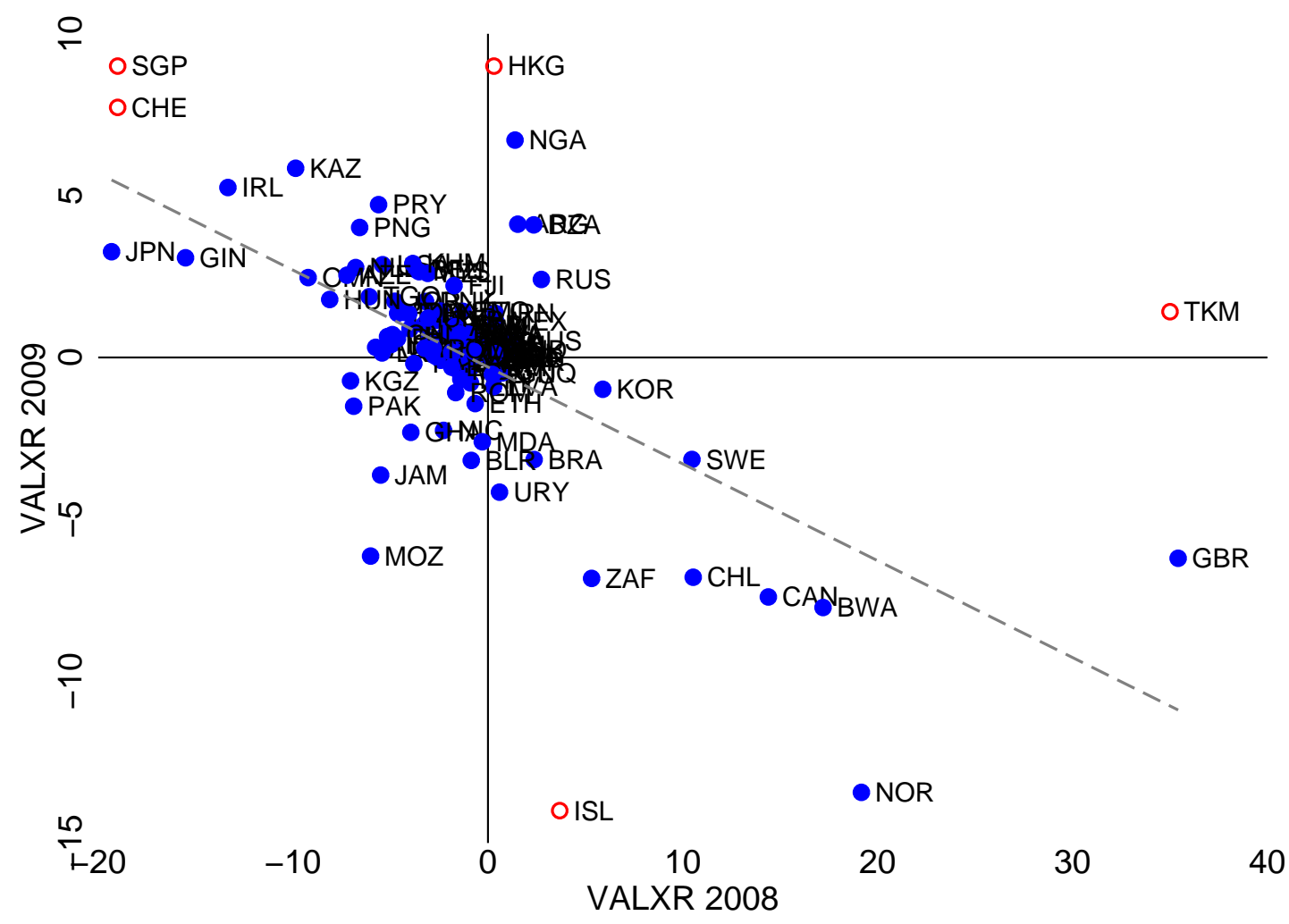

Note: $V A L X R$ are the exchange rate induced valuation effects scaled by GDP. This is defined by $V A L X R_{i t}=\% \Delta I_{i t}^{F} * I F I_{i t-1}$, where $\% \Delta I_{i t}^{F}$ is the percentage change in the aggregate net financial exchange rate index and $I F I_{i t}=\left(A_{i t}+L_{i t}\right) / G D P_{i t}$ is the International Financial Indicator index defined as the sum of foreign assets $\left(A_{i t}\right)$ plus foreign liabilities $\left(L_{i t}\right)$ scaled by GDP. $I_{t}^{F}$ is defined as $I_{t}^{F}=I_{t-1}^{F}\left(1+\sum \omega_{i j t-1}^{F} * \% \Delta E_{i j t}\right)$, where $\omega_{i j t-1}^{F}$ are the previous period net currency weight and $\% \Delta E_{i j t}$ is the percentage change in the bilateral nominal exchange rate. $\omega_{i j t}^{F}$ are the aggregate net financial weights defined as $\omega_{i j t}^{F}=\omega_{i j t}^{A} s_{i t}^{A}-\omega_{i j t}^{L} s_{i t}^{L}$. $\omega_{i j t}^{A}$ and $\omega_{i j t}^{L}$ are the weights for currency $j$ in period $t$ in country $i$ 's foreign assets and foreign liabilities. $s_{i t}^{A}=A_{i t} /\left(A_{i t}+L_{i t}\right)$ and $s_{i t}^{L}=$ $L_{i t} /\left(A_{i t}+L_{i t}\right)$ are the shares of foreign assets and foreign liabilities in total cross-border holdings. The correlation between these is -0.66. Regression line and correlation coefficient are computed excluding Iceland, Switzerland, Singapore, Hong Kong and Turkmenistan, as they exhibit extreme $V A L X R$ values. However, these countries are included with red circles with their positions being truncated to indicate the direction of $V A L X R$. 
Figure 8: Cumulative VALXR distribution

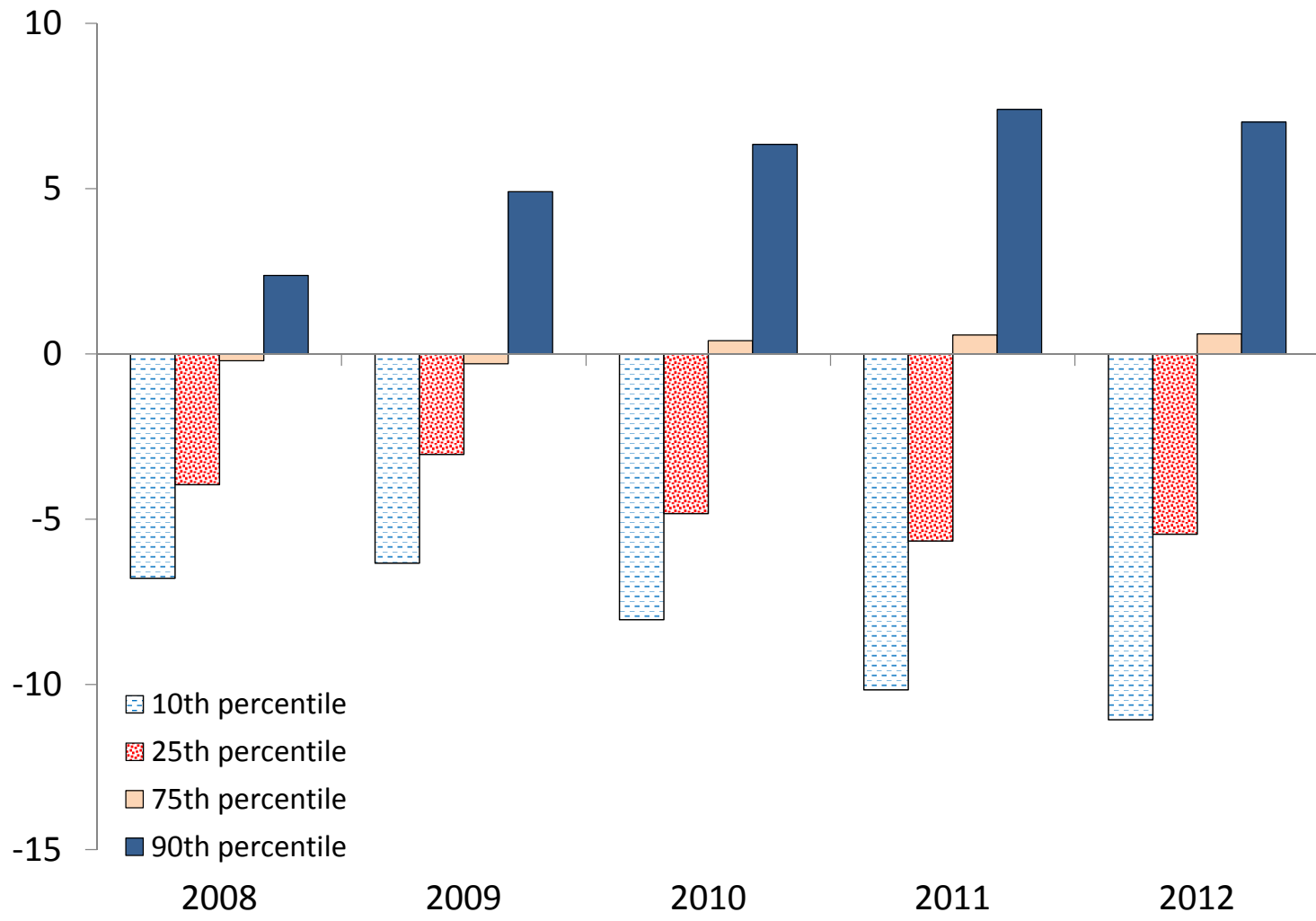

Note: These are the cumulative values for the $10^{t h}, 25^{t h}, 75^{t h}$ and $90^{\text {th }}$ percentiles of the $V A L X R$ distribution based on a sample of 117 countries (22 advanced plus 95 emerging/developing). $V A L X R$ are the exchange rate induced valuation effects scaled by GDP. This is defined by $V A L X R_{i t}=\% \Delta I_{i t}^{F} * I F I_{i t-1}$, where $\% \Delta I_{i t}^{F}$ is the percentage change in the aggregate net financial exchange rate index and $I F I_{i t}=\left(A_{i t}+L_{i t}\right) / G D P_{i t}$ is the International Financial Indicator index defined at the sum of foreign assets $\left(A_{i t}\right)$ plus foreign liabilities $\left(L_{i t}\right)$ scaled by GDP. $I_{t}^{F}$ is defined as $I_{t}^{F}=I_{t-1}^{F}\left(1+\sum \omega_{i j t-1}^{F} * \% \Delta E_{i j t}\right)$, where $\omega_{i j t-1}^{F}$ are the previous period net currency weight and $\% \Delta E_{i j t}$ is the percentage change in the bilateral nominal exchange rate. $\omega_{i j t}^{F}$ are the aggregate net financial weights defined as $\omega_{i j t}^{F}=\omega_{i j t}^{A} s_{i t}^{A}-\omega_{i j t}^{L} s_{i t}^{L}$. $\omega_{i j t}^{A}$ and $\omega_{i j t}^{L}$ are the weights for currency $j$ in period $t$ in country $i$ 's foreign assets and foreign liabilities. $s_{i t}^{A}=A_{i t} /\left(A_{i t}+L_{i t}\right)$ and $s_{i t}^{L}=L_{i t} /\left(A_{i t}+L_{i t}\right)$ are the shares of foreign assets and foreign liabilities in total cross-border holdings. 
Figure 9: VALXR counterfactual

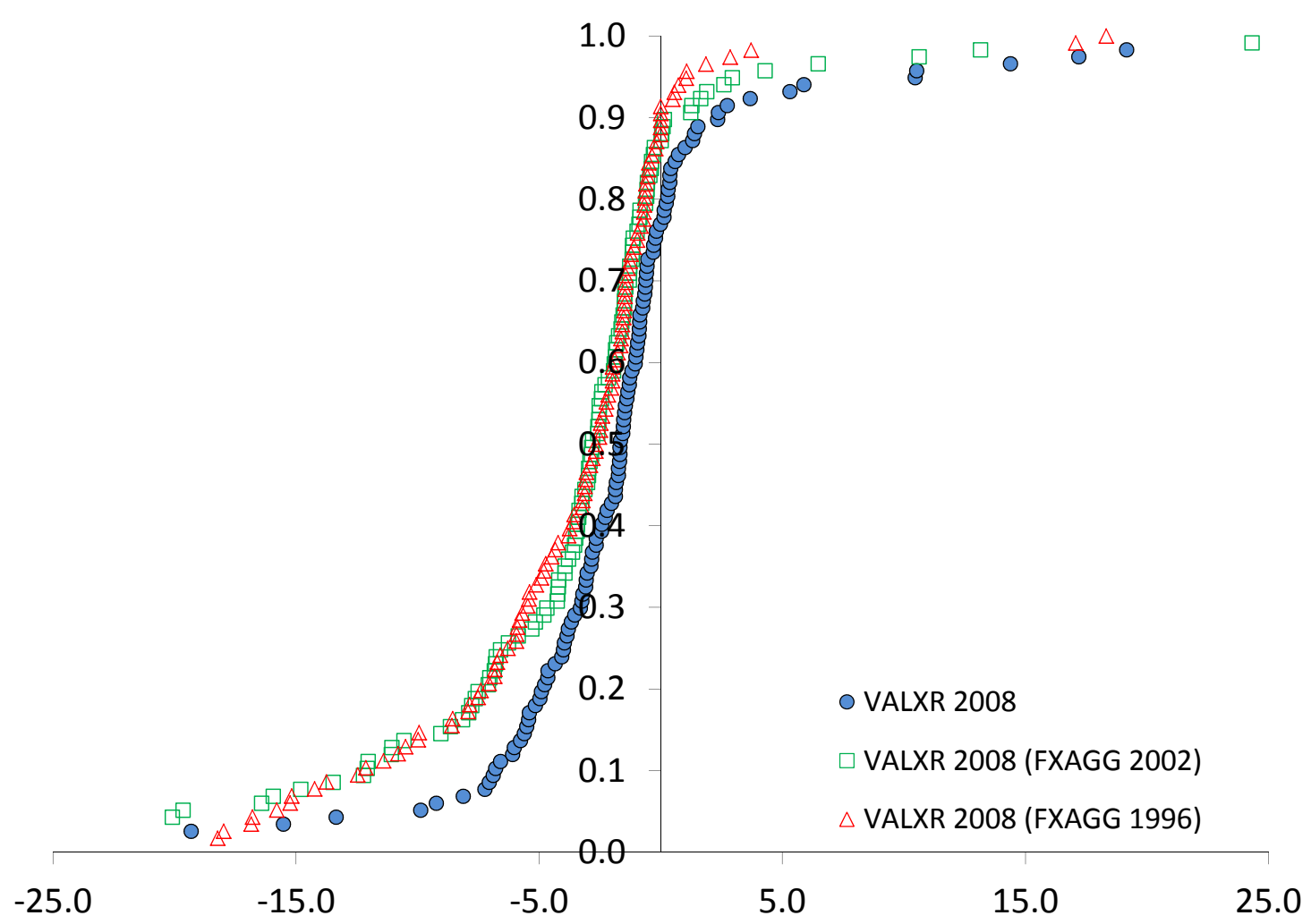

Note: $V A L X R$ are the exchange rate induced valuation effects scaled by GDP. This is defined by $V A L X R_{i t}=\% \Delta I_{i t}^{F} * I F I_{i t-1}$, where $\% \Delta I_{i t}^{F}$ is the percentage change in the aggregate net financial exchange rate index and $I F I_{i t}=\left(A_{i t}+L_{i t}\right) / G D P_{i t}$ is the International Financial Indicator index defined at the sum of foreign assets $\left(A_{i t}\right)$ plus foreign liabilities $\left(L_{i t}\right)$ scaled by GDP. $I_{t}^{F}$ is defined as $I_{t}^{F}=I_{t-1}^{F}\left(1+\sum \omega_{i j t-1}^{F} * \% \Delta E_{i j t}\right)$, where $\omega_{i j t-1}^{F}$ are the previous period net currency weight and $\% \Delta E_{i j t}$ is the percentage change in the bilateral nominal exchange rate. $\omega_{i j t}^{F}$ are the aggregate net financial weights defined as $\omega_{i j t}^{F}=\omega_{i j t}^{A} s_{i t}^{A}-\omega_{i j t}^{L} s_{i t}^{L}$. $\omega_{i j t}^{A}$ and $\omega_{i j t}^{L}$ are the weights for currency $j$ in period $t$ in country $i$ 's foreign assets and foreign liabilities. $s_{i t}^{A}=A_{i t} /\left(A_{i t}+L_{i t}\right)$ and $s_{i t}^{L}=$ $L_{i t} /\left(A_{i t}+L_{i t}\right)$ are the shares of foreign assets and foreign liabilities in total cross-border holdings. To compute these counterfactuals we use currency exposures in 1996 and 2002, and the exchange rate change as experienced in the crisis. More precisely, we take $\% \Delta E_{i j t}$ for 2007-2008, $\omega_{i j, 1996}^{F}$ and $\omega_{i j, 2002}^{F}$. 
Figure 10: VALX and VAL in 2008
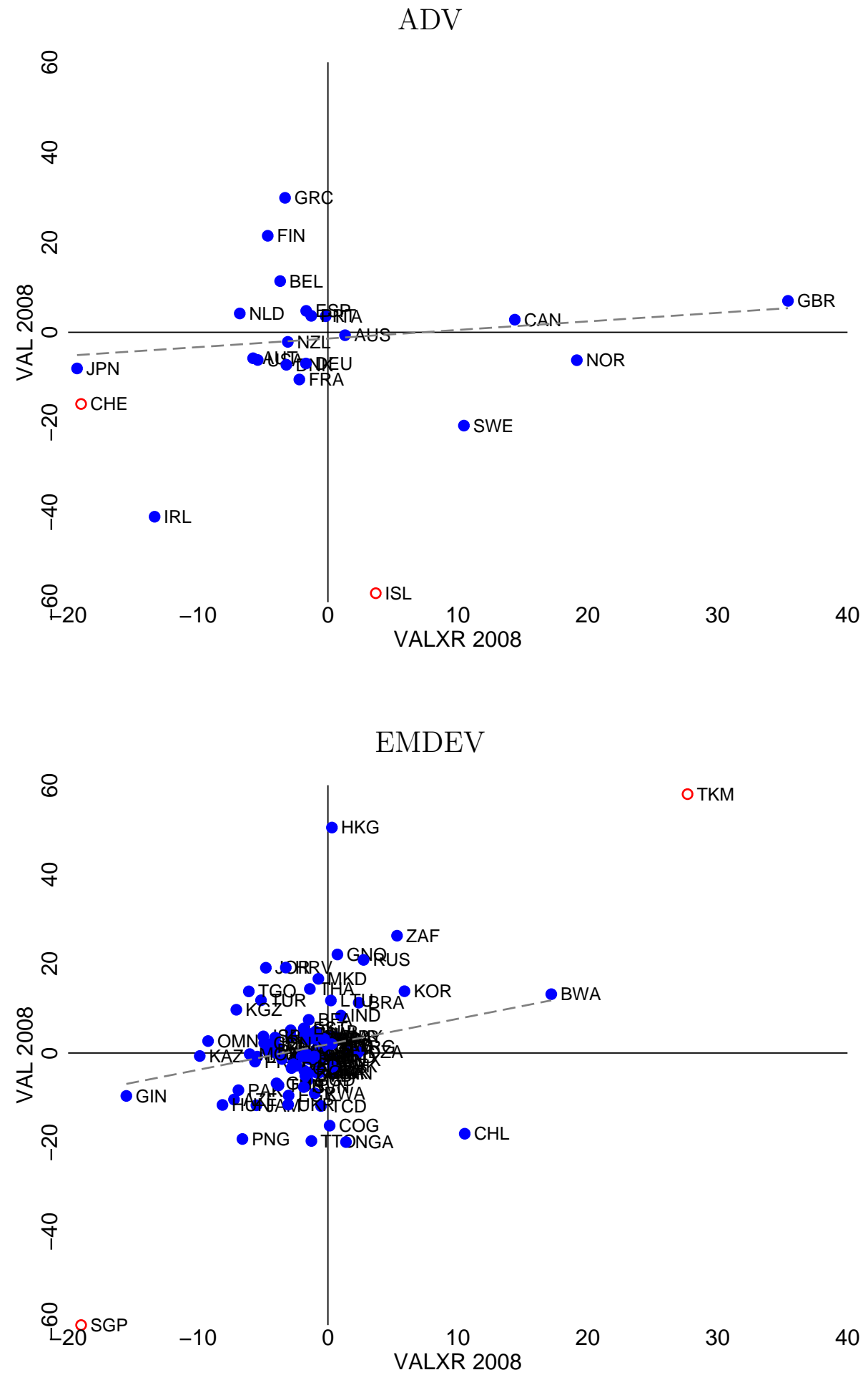

Note: $V A L$ is the net capital gain on the existing holdings of foreign assets and liabilities while $V A L X R$ is the part of net capital gain associated with exchange rate movements. Both are scaled by GDP. The correlation coefficient between $V A L$ and $V A L X R$ for ADV is 0.15 while for EMDEV is 0.22 . The regfession lines and correlation coefficients are computed excluding Iceland, Switzerland, Singapore, Hong Kong and Turkmenistan, as they exhibit extreme $V A L X R$ or $V A L$ values. However, these countries are included with red circles with their positions being truncated to indicate the direction of $V A L X R$ and $V A L$. 